\title{
Different Contribution of Redox-Sensitive Transient Receptor Potential Channels to Acetaminophen-Induced Death of Human Hepatoma Cell Line
}

\author{
Heba Badr ${ }^{1}$, Daisuke Kozai ${ }^{1}$, Reiko Sakaguchi ${ }^{1,2}$, Tomohiro Numata ${ }^{1,3}$ and \\ Yasuo Mori ${ }^{1,2,3 *}$ \\ ${ }^{1}$ Laboratory of Molecular Biology, Department of Synthetic Chemistry and Biological Chemistry, Graduate School of \\ Engineering, Kyoto University, Kyoto, Japan, ${ }^{2}$ World Premier International Research Initiative-Institute for Integrated \\ Cell-Material Sciences, Kyoto University, Kyoto, Japan, ${ }^{3}$ Laboratory of Environmental Systems Biology, Department of \\ Technology and Ecology, Hall of Global Environmental Studies, Kyoto University, Kyoto, Japan
}

OPEN ACCESS

Edited by:

Domenico Tricarico,

University of Bari Aldo Moro, Italy

Reviewed by:

Baruch Minke,

Hebrew University of Jerusalem, Israel Lane Brown,

Washington State University, USA

*Correspondence: Yasuo Mor

mori@sbchem.kyoto-u.ac.jp

Specialty section:

This article was submitted to Pharmacology of lon Channels and Channelopathies,

a section of the journal

Frontiers in Pharmacology

Received: 25 November 2015 Accepted: 21 January 2016 Published: 09 February 2016

Citation:

Badr H, Kozai D, Sakaguchi $R$, Numata T and Mori Y (2016) Different Contribution of Redox-Sensitive Transient Receptor Potential Channels to Acetaminophen-Induced Death of Human Hepatoma Cell Line.

Front. Pharmacol. 7:19.

doi: 10.3389/fphar.2016.00019
Acetaminophen (APAP) is a safe analgesic antipyretic drug at prescribed doses. Its overdose, however, can cause life-threatening liver damage. Though, involvement of oxidative stress is widely acknowledged in APAP-induced hepatocellular death, the mechanism of this increased oxidative stress and the associated alterations in $\mathrm{Ca}^{2+}$ homeostasis are still unclear. Among members of transient receptor potential (TRP) channels activated in response to oxidative stress, we here identify that redox-sensitive TRPV1, TRPC1, TRPM2, and TRPM7 channels underlie $\mathrm{Ca}^{2+}$ entry and downstream cellular damages induced by APAP in human hepatoma (HepG2) cells. Our data indicate that APAP treatment of HepG2 cells resulted in increased reactive oxygen species (ROS) production, glutathione (GSH) depletion, and $\mathrm{Ca}^{2+}$ entry leading to increased apoptotic cell death. These responses were significantly suppressed by pretreatment with the ROS scavengers $\mathrm{N}$-acetyl-L-cysteine (NAC) and 4,5-dihydroxy-1,3-benzene disulfonic acid disodium salt monohydrate (Tiron), and also by preincubation of cells with the glutathione inducer Dimethylfumarate (DMF). TRP subtype-targeted pharmacological blockers and siRNAs strategy revealed that suppression of either TRPV1, TRPC1, TRPM2, or TRPM7 reduced APAP-induced ROS formation, $\mathrm{Ca}^{2+}$ influx, and cell death; the effects of suppression of TRPV1 or TRPC1, known to be activated by oxidative cysteine modifications, were stronger than those of TRPM2 or TRPM7. Interestingly, TRPV1 and TRPC1 were labeled by the cysteine-selective modification reagent, 5,5'-dithiobis (2-nitrobenzoic acid)-2biotin (DTNB-2Bio), and this was attenuated by pretreatment with APAP, suggesting that APAP and/or its oxidized metabolites act directly on the modification target cysteine residues of TRPV1 and TRPC1 proteins. In human liver tissue, TRPV1, TRPC1, TRPM2, and TRPM7 channels transcripts were localized mainly to hepatocytes and Kupffer cells. Our findings strongly suggest that APAP-induced $\mathrm{Ca}^{2+}$ entry and subsequent hepatocellular death are regulated by multiple redox-activated cation channels, among which TRPV1 and TRPC1 play a prominent role.

Keywords: acetaminophen, oxidative stress, TRP channels, $\mathrm{Ca}^{2+}$ entry, HepG2, cell death 


\section{INTRODUCTION}

Acetaminophen ( $\mathrm{N}$-acetyl-para-aminophenol, APAP) is a widely used and safe over-the-counter analgesic antipyretic drug (Rumack, 2004). However, an accidental APAP overdose can result in potentially lethal hepatotoxicity in both humans and experimental animals (Thomas, 1993; Hinson et al., 2010). Adverse reactions of APAP account for a substantial number of acute liver failure cases necessitating liver transplantation (Larson et al., 2005; Myers et al., 2007; Chun et al., 2009). Determining the exact pathways underlying APAPinduced hepatocellular death should provide important cues for preventing its lethal side effects.

It has been established that APAP overdose causes a constellation of co-related cellular events (Hinson et al., 2010). APAP is largely converted by hepatic cytochrome P450dependent oxidases to a reactive intermediate metabolite, which depletes glutathione (GSH) and covalently binds to cellular proteins and lipids. Research on its mechanisms of toxicity has recently focused on oxidative stress exerted through accumulation of reactive oxygen species (ROS) and reactive nitrogen species (RNS), due to the depletion of GSH. APAP also causes mitochondrial dysfunction, deregulation of $\mathrm{Ca}^{2+}$ homeostasis, and DNA fragmentation (Muriel, 2009; Hinson et al., 2010). Furthermore, increased intracellular $\mathrm{Ca}^{2+}$ $\left(\left[\mathrm{Ca}^{2+}\right]_{\mathrm{i}}\right)$ induces the mitochondrial membrane permeability transition (MPT), which promotes ROS production, loss of mitochondrial potential, cessation of ATP synthesis and eventually hepatocellular apoptosis or necrosis (Bessems and Vermeulen, 2001). Though, increased $\left[\mathrm{Ca}^{2+}\right]_{i}$ in hepatocytes is a consequence of APAP overdose, how GSH depletion/ROS accumulation, $\left[\mathrm{Ca}^{2+}\right]_{\mathrm{i}}$ increases and mitochondrial dysfunction interact to induce APAP overdose-induced hepatocellular death remains elusive.

Transient receptor potential (TRP) proteins and their homologs have six putative transmembrane segments that assemble in tetramers to form $\mathrm{Ca}^{2+}$-permeable non-selective cation channels that regulate $\left[\mathrm{Ca}^{2+}\right]_{\mathrm{i}}$ levels (Clapham, 2003; Voets and Nilius, 2003). Mammalian TRP channels are classified into six subfamilies: TRPV, TRPC, TRPM, TRPA, TRPP, and TRPML and are activated by myriad extra- or intracellular physical and chemical stimuli (Numata et al., 2011). Members of the TRPV, TRPC, TRPM, and TRPA subclasses were reported to act as potential sensors of changes in cellular redox status and to contribute to ROS-induced $\left[\mathrm{Ca}^{2+}\right]_{\mathrm{i}}$ increases (Numata

\footnotetext{
Abbreviations: 2-APB, 2-aminoethyl diphenylborinate; AA861, 2-(12hydroxydodeca-5,10-diynyl)-3,5,6-trimethyl-p-benzoquinone; AITC, allyl isothiocyanate; APAP, N-acetyl-para-aminophenol; bp, base pair; $\left[\mathrm{Ca}^{2+}\right]_{\mathrm{i}}$, intracellular $\mathrm{Ca}^{2+}$ concentration; $\mathrm{CPZ}$, capsazepine; CsA, cyclosporine A; CTZ, clotrimazole; DCF-DA, 2,7-dichlorofluorescein diacetate; DMF, dimethylfumarate; $\mathrm{H}_{2} \mathrm{O}_{2}$, hydrogen peroxide; HepG2, human hepatoma cell line; MAPK, mitogen activated protein kinase; MPT, mitochondrial permeability transition; NAC, Nacetyl-L-cysteine; PI, propidium iodide; RT-PCR, reverse transcriptase polymerase chain reaction; siRNA, small interfering RNA; tiron, 4,5-dihydroxy-1,3-benzene disulfonic acid disodium salt monohydrate; TRP, transient receptor potential; W-7, N-(6-aminohexyl)-5-chloro-1-naphthalene sulfonamide; WI-38, human lung fibroblast cell line.
}

et al., 2011; Takahashi et al., 2011; Kozai et al., 2014b). Several TRP family channels have been detected in liver cells (Fonfria et al., 2006; Rychkov and Barritt, 2011). TRPC1 and TRPM7 were reported to be expressed in H4-IIE rat liver hepatoma cell lines (Brereton et al., 2001; Barritt et al., 2008), while TRPM2 channels were recently linked to APAP-induced oxidative stress and $\mathrm{Ca}^{2+}$ overload in mouse hepatocytes (Kheradpezhouh et al., 2014). However, expression and localization of such redoxsensitive TRP channels in human liver tissues have not been thoroughly investigated. It remains an open question how respective redox-sensitive TRP channels expressed in human hepatocytes contribute to $\mathrm{Ca}^{2+}$ entry and cell death induced by APAP overdose.

The goal of the present study was to profile redox-sensitive TRP channels expressed in human hepatoma cell line (HepG2), serving as a model of human liver hepatocytes, and to investigate the roles of these channels in APAP-induced oxidative stress, $\mathrm{Ca}^{2+}$ influx and consequent cell death. Our study included assessment of the ameliorative effects of ROS scavengers or GSH inducers on $\mathrm{Ca}^{2+}$ influx during APAP overdose, relevant to expression of these channels. To profile cell-specific expression of redox-sensitive TRP channels, in situ hybridization was used to map cellular distribution of TRP mRNAs in normal human liver tissue sections. Our results identified, for the first time, the redoxactivated TRPV1, TRPC1, TRPM2, and TRPM7 channels as being critical in the mechanism of APAP-induced $\mathrm{Ca}^{2+}$ entry and subsequent HepG2 cell death. These channels were confirmed to be localized to human liver hepatocytes. Among these channels, functional inhibition by pharmacological agents and expression suppression by siRNA strategy revealed that the contributions of TRPV1 and TRPC1 to APAP-induced responses of HepG2 cells were bigger than those of the other TRP channels. These TRP channels might represent new therapeutic targets for reducing hepatocellular damage caused by APAP overdoses.

\section{MATERIALS AND METHODS}

\section{Reagents}

$\mathrm{N}$-acetyl-para-aminophenol (APAP), capsazepine (CPZ), 2-aminoethyl diphenylborinate (2-APB), clotrimazole (CTZ), 2-(12-hydroxydodeca-5,10-diynyl)-3,5,6-trimethylp-benzoquinone (AA861), N-acetyl-L-cysteine (NAC), dimethylfumarate (DMF), metaphosphoric acid, triethanolamine, and cyclosporine A (CsA) were from SigmaAldrich (St. Louis, MO, USA). Hydrogen peroxide $\left(\mathrm{H}_{2} \mathrm{O}_{2}\right)$ was from Wako Pure Chemical Industries (Osaka, Japan). 4,5-Dihydroxy-1,3-benzene disulfonic acid disodium salt monohydrate (tiron) was from Tokyo Kasei Kogyo chemical Co. Ltd. (Tokyo, Japan). Mitogen activated protein kinase (MAPK) inhibitors including extracellular signal-regulated kinase (ERK) inhibitor, (U0126), c-jun N-terminal kinase (JNK) inhibitor, (SP600125), and p38 kinase inhibitor, (SB203580) were from Calbiochem (La Jolla, CA, USA). N-(6-Aminohexyl)-5chloro-2-naphthalenesulfonamide (W-7) was from Santa Cruz Biotechnology (Santa Cruz, CA, USA). Allyl isothiocyanate (AITC) was from Nacalai Tesque Inc. (Kyoto, Japan). 


\section{cDNA Cloning and Recombinant Plasmid Construction}

The plasmids of pCI-neo vector carrying human TRPV1, human TRPV2, human TRPV3, human TRPV4, mouse TRPC1, mouse TRPC4 $\beta$, mouse TRPC5, human TRPM2, human TRPM7, and human TRPA1 were used as previously described (Yoshida et al., 2006; Takahashi et al., 2011). Plasmids of the pCI-neo vector carrying human TRPC1 were used as previously described (Mori et al., 2002).

\section{Cell Culture and cDNA Expression}

Human embryonic kidney cell lines (HEK293, HEK293T) and HepG2 were cultured in Dulbecco's modified Eagle's medium (DMEM) (Sigma) containing 10\% fetal bovine serum (FBS), 30 $\mathrm{U} / \mathrm{ml}$ penicillin, and $30 \mu \mathrm{g} / \mathrm{ml}$ streptomycin (Meiji Seika Pharma Co., Ltd., Tokyo, Japan). Human lung fibroblast (WI-38) cells were cultured in modified Eagle's medium (MEM) containing $10 \% \mathrm{FBS}, 30 \mathrm{U} / \mathrm{ml}$ penicillin, and $30 \mu \mathrm{g} / \mathrm{ml}$ streptomycin. All cells were grown at $37^{\circ} \mathrm{C}$ in a humidified atmosphere of $95 \%$ air, $5 \% \mathrm{CO}_{2}$. HepG2 (RCB1886) and WI-38 (RCB0702) cells were purchased from RIKEN BRC (Tsukuba, Japan).

HEK293 cells were co-transfected with the recombinant plasmids and pEGFP-F (Clontech Laboratories, Palo Alto, CA, USA) as a transfection marker using SuperFect Transfection Reagent (QIAGEN, Valencia, CA, USA) according to the manufacturer's instructions. Transfected cells were grown for $36-40 \mathrm{~h}$ prior to performing $\left[\mathrm{Ca}^{2+}\right]_{\mathrm{i}}$ measurements. HEK293T cells were transfected with the recombinant plasmids using Lipofectamine 2000 transfection reagent (Invitrogen, Life Technologies Corporation, Grand Island, NY, USA) according to the manufacturer's instructions and the transfected HEK293T cells were grown for $36 \mathrm{~h}$ prior to performing in situ hybridization.

\section{siRNA Construction}

Small interfering RNA (siRNA) sequences targeting the coding regions of human TRPV1 mRNA (5'-AACCTATGTAATTCT CACCTACATCCT- $\left.3^{\prime}\right)$, human TRPC1 mRNA (5'-AAGCTT TTCTTGCTGGCGTGC-3'), human TRPM2 mRNA (5'-AAA GCCTCAGTTCGTGGATTCTT- $3^{\prime}$ ), and human TRPM7 mRNA ( $5^{\prime}$-AAGAACAAGCTATGCTTGATGCT-3') were used. The oligonucleotide sequence used for synthesis of non-targeting siRNA is $5^{\prime}$-GGGTATACTAGTGAATTAG-3' (forward) and $5^{\prime}$-CTAATTCACTAGTATACCC-3' (reverse). To construct siRNA oligomers, the Silencer siRNA Construction Kit (Ambion, Life Technologies Corporation, Carlsbad, CA, USA) was used according to the manufacturer's protocol. Transfection of siRNAs at $100 \mathrm{nM}$ for human TRPV1, human TRPC1, and human TRPM2 or $300 \mathrm{nM}$ for human TRPM7 to HepG2 cells were carried out using Lipofectamine 2000. Cells were treated with siRNAs of human TRPV1 or human TRPC1 for $24 \mathrm{~h}$ and siRNAs of human TRPM2 or human TRPM7 for $48 \mathrm{~h}$. They were then subjected to RT-PCR, western blotting, $\left[\mathrm{Ca}^{2+}\right]_{\mathrm{i}}$ measurements, intracellular ROS measurements, trypan blue exclusion assays, Hoechst 33342 /propidium iodide (PI) assays, caspase $3 / 7$ activity assays, or assessment of intracellular cytochrome c levels, as indicated in the individual experiments.

\section{$\left[\mathrm{Ca}^{2+}\right]_{\mathrm{i}}$ Measurements}

Transfected HEK293, HepG2, and siRNA-transfected HepG2 cells were subjected to $\left[\mathrm{Ca}^{2+}\right]_{\mathrm{i}}$ measurements $3-16 \mathrm{~h}$ after plating onto poly-L-lysine-coated glass coverslips. Fura-2-AM (Dojindo, Kumamoto, Japan) fluorescence was measured in HEPES-buffered saline (HBS) containing the following: $107 \mathrm{mM}$ $\mathrm{NaCl}, 6 \mathrm{mM} \mathrm{KCl}, 1.2 \mathrm{mM} \mathrm{MgSO}_{4}, 2 \mathrm{mM} \mathrm{CaCl}_{2}, 11.5 \mathrm{mM}$ glucose, and $20 \mathrm{mM}$ HEPES ( $\mathrm{pH}$ was adjusted to 7.4 with $\mathrm{NaOH}$ ). Fluorescence images of cells were recorded and analyzed with the video image analysis system AQUACOSMOS (Hamamatsu Photonics, Shizuoka, Japan) according to the manufacturer's instructions. The $340: 380 \mathrm{~nm}$ ratio images were obtained on a pixel-by-pixel basis. Fura-2 measurements were performed at $37^{\circ} \mathrm{C}$ in HEPES-buffered saline. The $340: 380 \mathrm{~nm}$ ratio images were converted to $\mathrm{Ca}^{2+}$ concentrations by in vivo calibration using $10 \mu \mathrm{M}$ ionomycin (Calbiochem/EMD Chemicals, San Diego, CA, USA) as described previously (Takahashi et al., 2008).

\section{Reverse Transcriptase Polymerase Chain Reaction (RT-PCR) and PCR}

Total RNA from HepG2, WI-38, and siRNA-transfected HepG2 cells was extracted using ISOGEN (Wako Pure Chemical Industries) according to the manufacturer's instructions. The concentration and purity of RNA were determined using a NanoVue Plus spectrophotometer (GE Healthcare Life Science, Chalfont, Buckinghamshire, UK). Total RNA samples $(0.2 \mu \mathrm{g})$ were reverse-transcribed at $42^{\circ} \mathrm{C}$ for $30 \mathrm{~min}$ with Avian Myeloblastosis virus reverse transcriptase using the RNA LA PCR kit (TaKaRa-Bio, Shiga, Japan). Expression levels of TRPV14, TRPC1, TRPC4, TRPC5, TRPM2, TRPM7, and TRPA1 in the cDNA from HepG2 and the cDNA library of human liver (TaKaRa-Bio, Code No. 9505, Lot No. A602) were determined by PCR. TRPA1 expression in the cDNA of WI38 cells was also determined by PCR. As a positive control, we amplified the glyceraldehyde-3-phosphate-dehydrogenase (GAPDH) sequence. Suppression of RNA expression was confirmed by RT-PCR analysis. PCR was performed with LA Taq polymerase $(\mathrm{TaKaRa})$ and conducted in a thermal cycler (Gene Amp PCR System 9600, Perkin Elmer Life Sciences, Boston, MA, USA) under the following conditions: initial heating at $94^{\circ} \mathrm{C}$ for $2 \mathrm{~min}$, followed by $32-35$ cycles of denaturation at $94^{\circ} \mathrm{C}$ for $2 \mathrm{~min}$, annealing at $55-63^{\circ} \mathrm{C}$ for $1 \mathrm{~min}$ and final extension at $72^{\circ} \mathrm{C}$ for $1 \mathrm{~min}$. Sequences of gene-specific primers (synthesized by Sigma-Aldrich), predicated lengths of PCR products and experimental conditions are listed in Table 1.

\section{Western Blot Analysis}

HepG2 and siRNA-transfected HepG2 cells were lysed in ice-cold lysis RIPA buffer [50 mM Tris- $\mathrm{HCl}$ ( $\mathrm{pH} 8.0$ ), $150 \mathrm{mM}$ $\mathrm{NaCl}, 1 \% \mathrm{NP}-40,0.1 \%$ sodium dodecyl sulfate (SDS), $0.5 \%$ sodium deoxycholate, $0.1 \mathrm{mM}$ sodium orthovanadate, $1 \mathrm{mM}$ phenylmethylsulfonyl fluoride, $10 \mu \mathrm{g} / \mathrm{ml}$ leupeptin, and $5 \mu \mathrm{g} / \mathrm{ml}$ aprotinin] at $4{ }^{\circ} \mathrm{C}$ for $30 \mathrm{~min}$. The supernatant, containing protein, was collected by centrifuging at $15,000 \mathrm{rpm}$ for $20 \mathrm{~min}$ at $4^{\circ} \mathrm{C}$. Protein concentrations of samples were determined using a Pierce BCA Protein Assay kit (Thermo Fisher Scientific, Rockford, IL, USA) and samples were fractionated 
TABLE 1 | Primer sequences used in RT-PCR experiments.

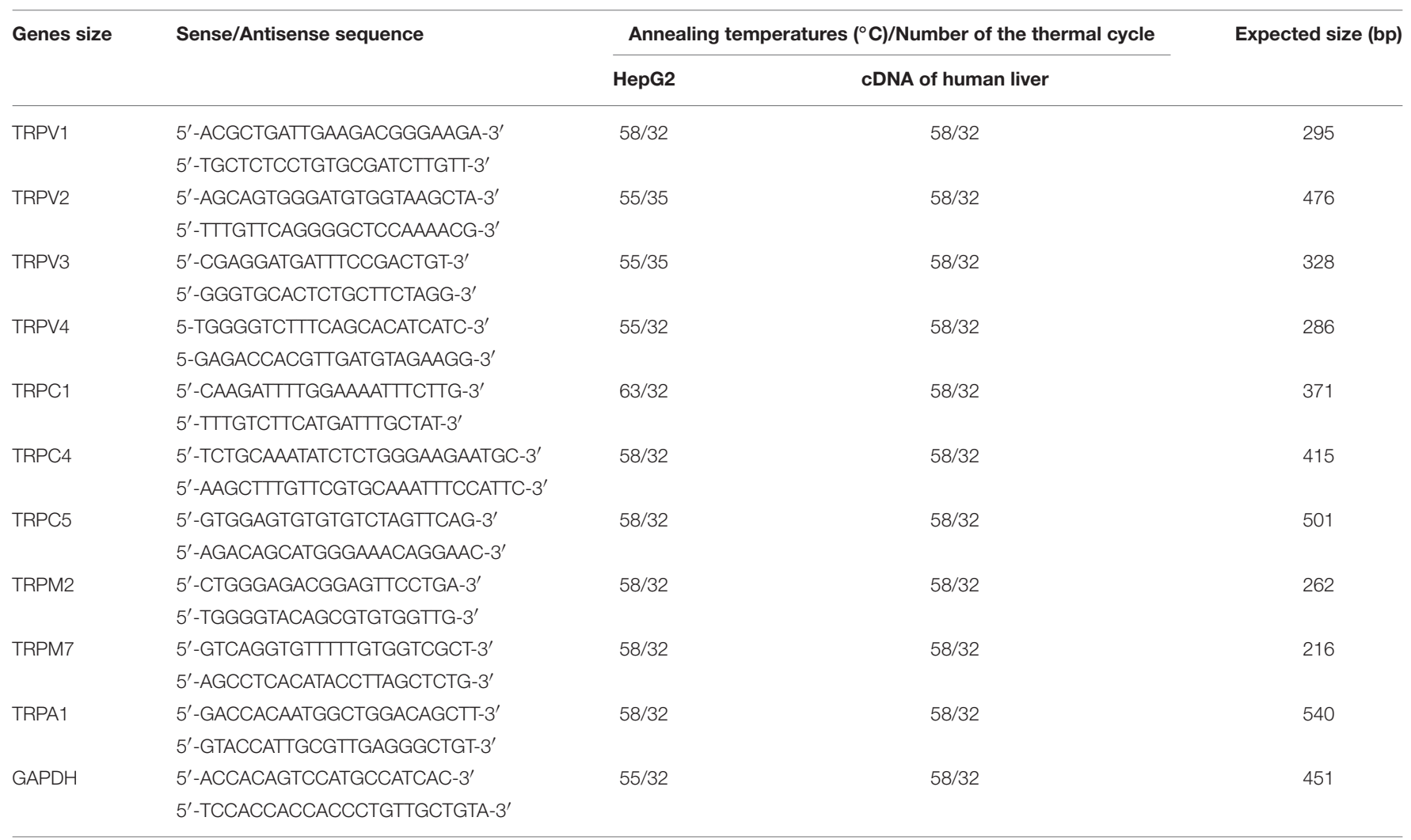

by electrophoresis through $7.5 \%$ SDS-polyacrylamide gel electrophoresis (SDS-PAGE). Protein bands were then transferred onto a polyvinylidene difluoride (PVDF) membrane (Millipore Corp, Bedford, MA, USA). TRPV1, TRPC1, TRPM2, and TRPM7 were detected by western blotting using anti-TRPV1 (1:1000, Santa Cruz Biotechnology, sc-12498), anti-TRPC1 (1:1000, Alomone Laboratory, Jerusalem, Israel, ACC-010), anti-TRPM2 (1:1000; Lange et al., 2009), and anti-TRPM7 antibodies (1:1000; Hanano et al., 2004), respectively, with detection by the ECL system (Amersham Pharmacia Biotech, Piscataway, NJ). For loading normalization, $\alpha$-tubulin was detected with an anti- $\alpha$-tubulin antibody (1:3000, SigmaAldrich, T6074). Chemiluminescence was detected by the luminescent image analyzer LAS-3000 (Fuji film, Tokyo, Japan). The intensity of the protein bands observed for TRPV1, TRPC1, TRPM2, and TRPM7 was quantified and normalized to the intensity of $\alpha$-tubulin bands using the ImageJ software.

\section{DTNB-2Bio Labeling Assay}

The 5,5'-dithiobis (2-nitrobenzoic acid)-2biotin (DTNB-2Bio) labeling assay was performed as previously described (Yoshida et al., 2006). HEK293T cells transfected with human TRPV1GFP, human TRPV4-GFP, human TRPC1-Flag, or vector $(5 \times$ $10^{6}$ cells) were washed with phosphate-buffered saline (PBS). Cell surface membranes were permeabilized with PBS containing $0.001 \%$ digitonin (Sigma) for $5 \mathrm{~min}$. Cells were then collected and incubated in HBS solution with or without $20 \mathrm{mM}$ APAP for $3 \mathrm{~h}$ at $37^{\circ} \mathrm{C}$ followed by $100 \mu \mathrm{M}$ DTNB-2Bio for $40 \mathrm{~min}$ at room temperature. Cells were washed with HBS and lysed in RIPA buffer ( $\mathrm{pH} 8.0$ ). Cell lysates were incubated batchwise with NeutrAvidin-Plus beads (Thermo-Scientific) overnight at $4^{\circ} \mathrm{C}$ with constant shaking. Beads were rinsed three times with RIPA buffer by centrifugation at $15,000 \mathrm{rpm}$ for $1 \mathrm{~min}$. Proteins were eluted in RIPA buffer containing $50 \mathrm{mM}$ dithiothreitol (DTT) for $60 \mathrm{~min}$ and denatured in SDS sample buffer containing $50 \mathrm{mM}$ DTT for $30 \mathrm{~min}$ at room temperature. Proteins were analyzed by 7.5\% SDS-PAGE, transferred to a PVDF membrane, and detected by western blotting with an anti-GFP (Clontech) or anti-Flag (Sigma) antibody.

\section{Intracellular Reactive Oxygen Species (ROS) Measurements}

Intracellular ROS levels in HepG2 cells were measured using 2,7-dichlorofluorescein diacetate (DCF-DA, Sigma-Aldrich) following the manufacture's protocol. Cells were incubated with $20 \mu \mathrm{M}$ DCF-DA dissolved in Hanks' balanced salt solution (HBSS) in the dark for $45 \mathrm{~min}$ at $37^{\circ} \mathrm{C}$, then washed once with HBSS. After loading in this manner, cells were stimulated with APAP or $\mathrm{H}_{2} \mathrm{O}_{2}$, with or without inhibitors, for $3 \mathrm{~h}$. Fluorescence intensity was measured using a Tecan Infinite M200 microplate reader (Tecan Group Ltd., Mannedorf, Switzerland) with excitation and emission wavelengths of 485 and $530 \mathrm{~nm}$, respectively. 


\section{Reduced Glutathione (GSH) Measurements} GSH content of HepG2 cells was determined using a GSH assay kit (Cayman Chemical Co., Ann Arbor, MI, USA), according to the manufacturer's instructions. This assay was performed on cells that had been treated with APAP or $\mathrm{H}_{2} \mathrm{O}_{2}$, with or without ROS scavengers (NAC, and tiron) or GSH inducer (DMF). Absorbance was measured at $410 \mathrm{~nm}$ on a 96-well plate using a Tecan Infinite M200 microplate reader. Samples and standards were assayed three times in triplicate. The concentrations of GSH were calculated from a standard curve produced using a range of known GSH concentrations.

\section{Trypan Blue Exclusion Assay}

Cell viability was assessed by trypan blue exclusion by counting cells after a 5 min incubation with $0.4 \%$ trypan blue (Maeno et al., 2000). Data are represented as the mean values of triplicates from each separate experiment.

\section{Hoechst33342 and Propidium lodide (PI) Cell Death Assays}

Cell death was evaluated by staining cells with Hoechst 33342 (2' - [4-ethoxyphenyl] -5- [4-methyl -1-piperazinyl] -2,5'-bi - $1 \mathrm{H}$ benzimidazole trihydrochloride trihydrate solution; Dojindo) and propidium iodide (PI; Setareh Biotech, Eugene, OR, USA). After $24 \mathrm{~h}$ stimulation with various test reagents, as indicated for the individual experiments, cells were incubated with Hoechst33342 $(1 \mu \mathrm{g} / \mathrm{ml})$ and PI $(0.2 \mu \mathrm{g} / \mathrm{ml})$ for $10 \mathrm{~min}$ at $37^{\circ} \mathrm{C}$ in $95 \%$ air, $5 \% \mathrm{CO}_{2}$ to stain the nuclei and dead cells, respectively. Staining was visualized under a fluorescence microscope (Olympus IX81, Olympus, Tokyo, Japan) with MetaMorph software (Molecular Devices). The proportion of dead cells was calculated by dividing the number of PI-positive cells by the number of nuclei and this was expressed as percent PI-positive cells.

\section{Caspase 3/7 Enzymatic Activity Assay}

To detect caspase $3 / 7$ activity, HepG2 cells $\left(2 \times 10^{5}\right.$ cells per well $)$ were cultured in 96-well plates. After overnight adherence, cells were stimulated with APAP or $\mathrm{H}_{2} \mathrm{O}_{2}$, with or without inhibitors, and caspase 3/7 activity analyzed using ApoONE Homogeneous Caspase 3/7 Assay kit (Promega, Madison, WI, USA) according to the manufacturer's instructions. Fluorescence was read at an excitation wavelength of $485 \mathrm{~nm}$ and emission wavelength of $527 \mathrm{~nm}$ using a Tecan Infinite M200 microplate reader.

\section{Measurements of Cytochrome C Release}

To detect levels of cytochrome $\mathrm{c}$ released, HepG2 cells $\left(1 \times 10^{6}\right.$ cells) were plated in a $6-\mathrm{cm}$ cell culture dish. After overnight adherence, cells were stimulated with APAP or $\mathrm{H}_{2} \mathrm{O}_{2}$ with or without inhibitors, then harvested by scraping, washed with cold PBS and re-suspended in ice-cold cytosol extraction buffer containing $10 \mathrm{mM}$ Tris $\mathrm{pH} 7.4,100 \mathrm{mM} \mathrm{NaCl}, 1 \mathrm{mM}$ EDTA, $1 \mathrm{mM}$ EGTA, $1 \mathrm{mM} \mathrm{NaF}, 20 \mathrm{mM} \mathrm{Na}_{4} \mathrm{P}_{2} \mathrm{O}_{7}, 2 \mathrm{mM} \mathrm{Na} \mathrm{VO}_{4}$, $1 \%$ Triton X-100, 10\% glycerol, $0.1 \%$ SDS, $0.5 \%$ deoxycholate, and protease inhibitor $(0.1 \mathrm{mM}$ sodium orthovanadate, $1 \mathrm{mM}$ phenylmethylsulfonyl fluoride, $10 \mu \mathrm{g} / \mathrm{ml}$ leupeptin, and $5 \mu \mathrm{g} / \mathrm{ml}$ aprotinin). The cell lysate was centrifuged at $10,000 \mathrm{rpm}$ for
$30 \mathrm{~min}$ at $4^{\circ} \mathrm{C}$. The supernatant (cytosolic fraction) was collected and stored at $80^{\circ} \mathrm{C}$. A cytochrome c ELISA kit (Invitrogen, Carlsbad, CA, USA) was used to estimate cytochrome c protein content in the HepG2 cell extracts according to the manufacturer's instructions. Measurements were performed in triplicate and the absorbance at $450 \mathrm{~nm}$ was determined with a Tecan Infinite M200 microplate reader. Cytochrome c levels were calculated from a standard curve produced with a range of known cytochrome c concentrations.

\section{DNA Fragmentation Assay}

To detect DNA fragmentation, HepG2 cells $\left(1 \times 10^{6}\right.$ cells $)$ were plated on $6-\mathrm{cm}$ culture plates and allowed to adhere overnight. Cells were then treated with various doses of APAP or $\mathrm{H}_{2} \mathrm{O}_{2}$ for $24 \mathrm{~h}$, collected by scraping and centrifuged at $1000 \times \mathrm{g}$ for $3 \mathrm{~min}$ at $4^{\circ} \mathrm{C}$. DNA was then isolated using the Apoptosis Ladder Detection Kit (Wako Pure Chemical Industries Inc.) according to the manufacturer's protocol. DNA fragments were electrophoretically separated on a $1.5 \%$ agarose gel in Tris-acetate EDTA buffer containing $40 \mathrm{mM}$ Tris acetate and $1 \mathrm{mM}$ EDTA. The bands were stained with SYBR ${ }^{\circledR}$ Green I (Molecular probes Inc., Eugene, Oregon, USA).

\section{In situ Hybridization}

hTRPV1 (69-428), hTRPC1 (1419-1923), hTRPM2 (3889-4151), hTRPM7 (371-1020), and hTRPA1 (474-960) cDNA fragments were amplified from the plasmids of pCI-neo vector carrying human TRPV1, human TRPC1, human TRPM2, human TRPM7, and human TRPA1 using two sets of primers, summarized in Table 2, and cloned into pGEM-T Easy vector (Promega). In vitro transcription was performed using the digoxigenin (DIG) RNA Labeling Mix (Roche Applied Science, Roche Diagnostics Deutschland GmbH, Mannheim, Germany) for synthesis of the sense or antisense DIG-labeled RNA probes according to the manufacturer's protocol. In situ hybridization of these transcripts was performed in HEK293T expressing TRP of interest or HepG2 cells according to the manufacturer's protocol. Human liver paraffin sections obtained from BioChain Institute, Inc. (San Leandro, CA, USA) were digested for $30 \mathrm{~min}$ at $37^{\circ} \mathrm{C}$ with a freshly prepared solution of proteinase $\mathrm{K}$ (Sigma-Aldrich) at a final concentration $5 \mu \mathrm{g} / \mathrm{ml}$ in $100 \mathrm{mM}$

TABLE 2 | Primer sequences used for the synthesis of the probes for in situ hybridization technique.

\begin{tabular}{ll}
\hline Genes & Sense/Antisense sequence \\
\hline TRPV1 & 5'-CCCCCTGGATGGAGACCCTA-3' \\
& 5'-CTGCAGAAGAGCAAGAAGCA-3' \\
TRPC1 & 5'-TTCTGTGGATATTGGGATGA-3' \\
& 5'-CAGAACAAAGCAAAGCAGGTG-3' \\
TRPM2 & 5'-CTGGGAGACGGAGTTCCTGA-3' \\
& 5'-TGGGGTACAGCGTGTGGTTG-3' \\
TRPM7 & 5-TCCAGGATGTCAAATTG-3' \\
& 5-TATGAAATGGGAATGCAG-3' \\
TRPA1 & 5'-CCCCTCTGCATTGTGCTGTA-3' \\
& 5'-AAAATGTGCCTGGACAATGG-3'
\end{tabular}


Tris- $\mathrm{HCl} / 50 \mathrm{mM}$ EDTA (pH 8.0). After deparaffinization and rehydration, sections were acetylated with $0.25 \%$ acetic anhydride in $0.1 \mathrm{M}$ triethanolamine ( $\mathrm{pH} 8.0$ ). Hybridization was performed for $14-16 \mathrm{~h}$ at $50^{\circ} \mathrm{C}$ with $400 \mathrm{ng} / \mathrm{ml}$ antisense or sense probe in $5 \times$ standard sodium citrate (SSC, $150 \mathrm{mM} \mathrm{NaCl}$ and $15 \mathrm{mM}$ sodium citrate, $\mathrm{pH}$ 7.4), 0.5 M EDTA (pH 8.0), $1 \times$ Denhardt's solution ( $0.02 \%$ Ficoll, $0.02 \%$ polyvinylpyrrolidone, $0.2 \mathrm{mg} / \mathrm{ml}$ RNasefree bovine serum albumin), $50 \mathrm{mg} / \mathrm{ml}$ Heparin, $10 \mathrm{mg} / \mathrm{ml}$ yeast tRNA, $10 \%$ Tween $20,10 \%$ CHAPS, $10 \%$ dextran sulfate, and $50 \%$ formamide. Sections were washed twice in $2 \times$ SSC with $50 \%$ formamide at $50^{\circ} \mathrm{C}$ for $15 \mathrm{~min}$. They were then washed further at increasingly high stringencies up to a final condition of $0.2 \times \mathrm{SSC}$ at $50^{\circ} \mathrm{C}$ for $20 \mathrm{~min}$. Washed slides were then incubated in a blocking reagent containing $100 \mathrm{mM}$ Tris- $\mathrm{HCl}$ ( $\mathrm{pH} 7.5), 150 \mathrm{mM} \mathrm{NaCl}, 1 \%$ normal goat serum (NGS), and $0.1 \%$ Triton X-100 at room temperature for $1 \mathrm{~h}$. Immunohistochemical detection of the hybridized probes was performed using alkaline phosphatase-conjugated anti-DIG antibody (Roche Applied Science, Cat. No. 11093274910) diluted to $1: 500$ in blocking buffer for $16 \mathrm{~h}$. Alkaline phosphatase activity was visualized by incubating for $16-24 \mathrm{~h}$ with nitroblue tetrazolium (Roche Applied Science) and 5-bromo-4-chloro-3indolyl phosphate (Roche Applied Science) in buffer containing $100 \mathrm{mM}$ Tris- $\mathrm{HCl}$ (pH 9.5), $50 \mathrm{mM} \mathrm{MgCl}_{2}, 100 \mathrm{mM} \mathrm{NaCl}$, and $1 \mathrm{mM}$ levamisole (Sigma-Aldrich), protected from light. The colorimetric reaction was stopped by washing sections twice for $10 \mathrm{~min}$ in buffer containing $0.1 \mathrm{M}$ Tris- $\mathrm{HCl}$ and $1 \mathrm{mM}$ EDTA, pH 8.0. Sections were then counterstained with $0.02 \%$ fast green FCF (Sigma-Aldrich) and coverslips were mounted with Entellan ${ }^{\circledR}$ New (Merck Millipore, Darmstadt, Germany). All sections were analyzed with an Olympus IX81 microscope.

\section{Statistical Analysis}

All data are expressed as means \pm SEM. We collected data for each condition from at least three independent experiments. Statistical analysis was performed with the Student's $t$-test for comparing two groups. In experiments involving more than two conditions, statistical analysis was performed with a one-way analysis of variance (ANOVA) and Bonferroni post-hoc analysis. A $P<0.05$ was considered statistically significant. All statistical analyses were performed using Prism 6.02 (GraphPad Software, Inc., San Diego, CA, USA).

\section{RESULTS}

\section{$\left[\mathrm{Ca}^{2+}\right]_{\mathrm{i}}$ Increases are Evoked by Acetaminophen and $\mathrm{H}_{2} \mathrm{O}_{2}$ in HepG2 Cells}

Intracellular signaling molecules such as $\mathrm{Ca}^{2+}$ and ROS normally regulate diverse cellular functions (Yan et al., 2006). Nonetheless, ROS-induced oxidative stress and impaired $\mathrm{Ca}^{2+}$ homeostasis could potentially contribute to hepatocellular death induced by APAP overdose (Hinson et al., 2010). We first tested whether APAP and $\mathrm{H}_{2} \mathrm{O}_{2}$ administration induced $\mathrm{Ca}^{2+}$ entry in HepG2 cells, using these cells as a model of human hepatocytes. Treatment of HepG2 cells with APAP at various

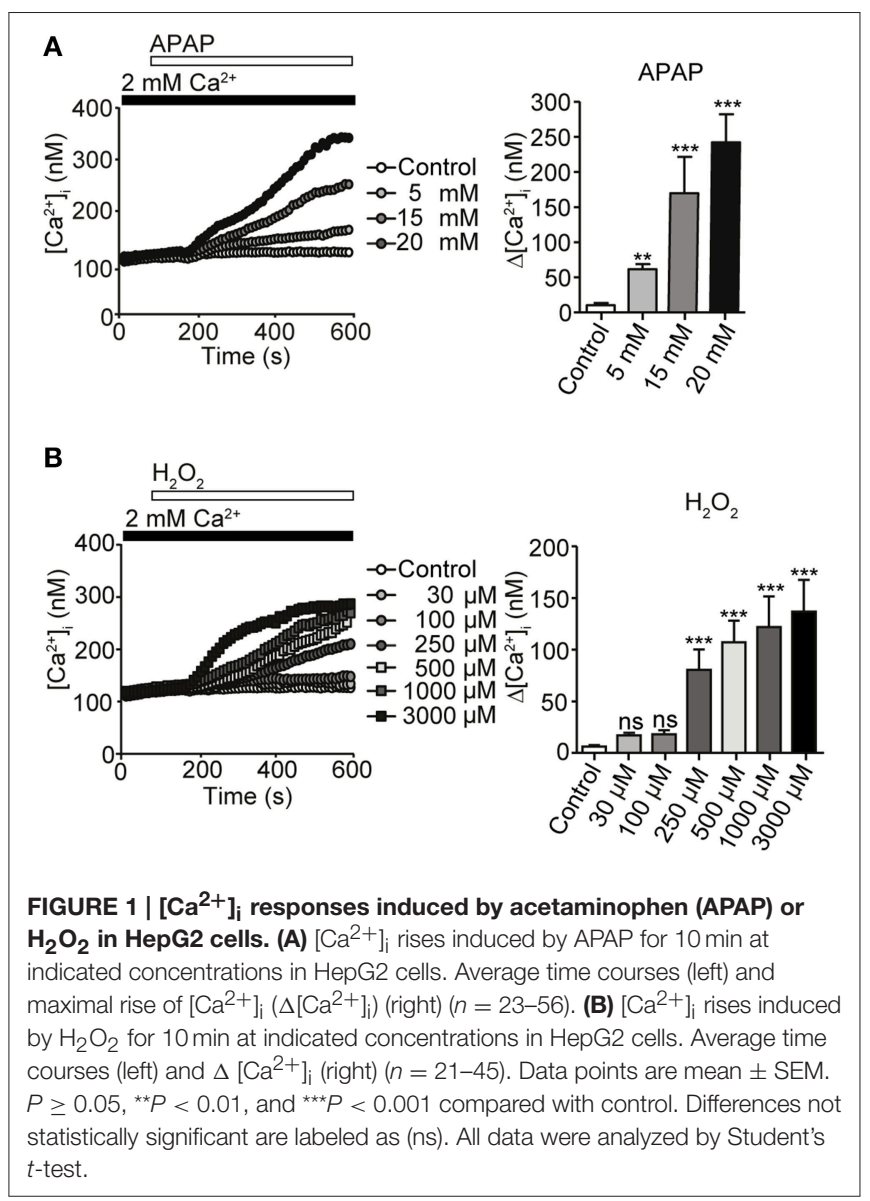

concentrations $(5,15$, or $20 \mathrm{mM})$ for $10 \mathrm{~min}$ resulted in a gradual, dose-dependent increase in $\left[\mathrm{Ca}^{2+}\right]_{\mathrm{i}}$ (Figure 1A), whereas $\mathrm{H}_{2} \mathrm{O}_{2}$ administration, at concentrations $>100 \mu \mathrm{M}$, evoked abrupt $\left[\mathrm{Ca}^{2+}\right]_{\mathrm{i}}$ increases at $37^{\circ} \mathrm{C}$ (Figure 1B). Thus, $\mathrm{Ca}^{2+}$ entry positively correlates with the dose of APAP and ROS used for stimulation.

\section{APAP-Evoked ROS Production Elicits $\mathrm{Ca}^{2+}$ Responses in hepG2 Cells}

APAP induces ROS generation (DeVries, 1981). We confirmed that treatment with $20 \mathrm{mM}$ APAP or $1 \mathrm{mM} \mathrm{H}_{2} \mathrm{O}_{2}$ for $3 \mathrm{~h}$ significantly increased ROS levels in HepG2 cells, as compared with in untreated controls. Pretreatment for $3 \mathrm{~h}$ with the ROS scavengers N-acetyl-L-cysteine (NAC) and tiron, each at $1 \mathrm{mM}$, significantly reduced ROS levels produced after treatment with either $20 \mathrm{mM}$ APAP or $1 \mathrm{mM} \mathrm{H}_{2} \mathrm{O}_{2}$ for additional $3 \mathrm{~h}$ (Figures 2A,B). Administration of either of the ROS scavengers alone did not significantly change ROS levels, as compared with those in untreated control cells. In $\left[\mathrm{Ca}^{2+}\right]_{\mathrm{i}}$ measurements, increases in $\left[\mathrm{Ca}^{2+}\right]_{\mathrm{i}}$ in response to $20 \mathrm{mM}$ of APAP or $1 \mathrm{mM}$ $\mathrm{H}_{2} \mathrm{O}_{2}$ were also significantly suppressed by pretreatment with either NAC or tiron, at $1 \mathrm{mM}$, for $6 \mathrm{~min}$ (Figures 2C,D). Together, these results indicate that ROS production evoked by APAP and $\mathrm{H}_{2} \mathrm{O}_{2}$ induces the $\mathrm{Ca}^{2+}$ responses in HepG2 cells. 

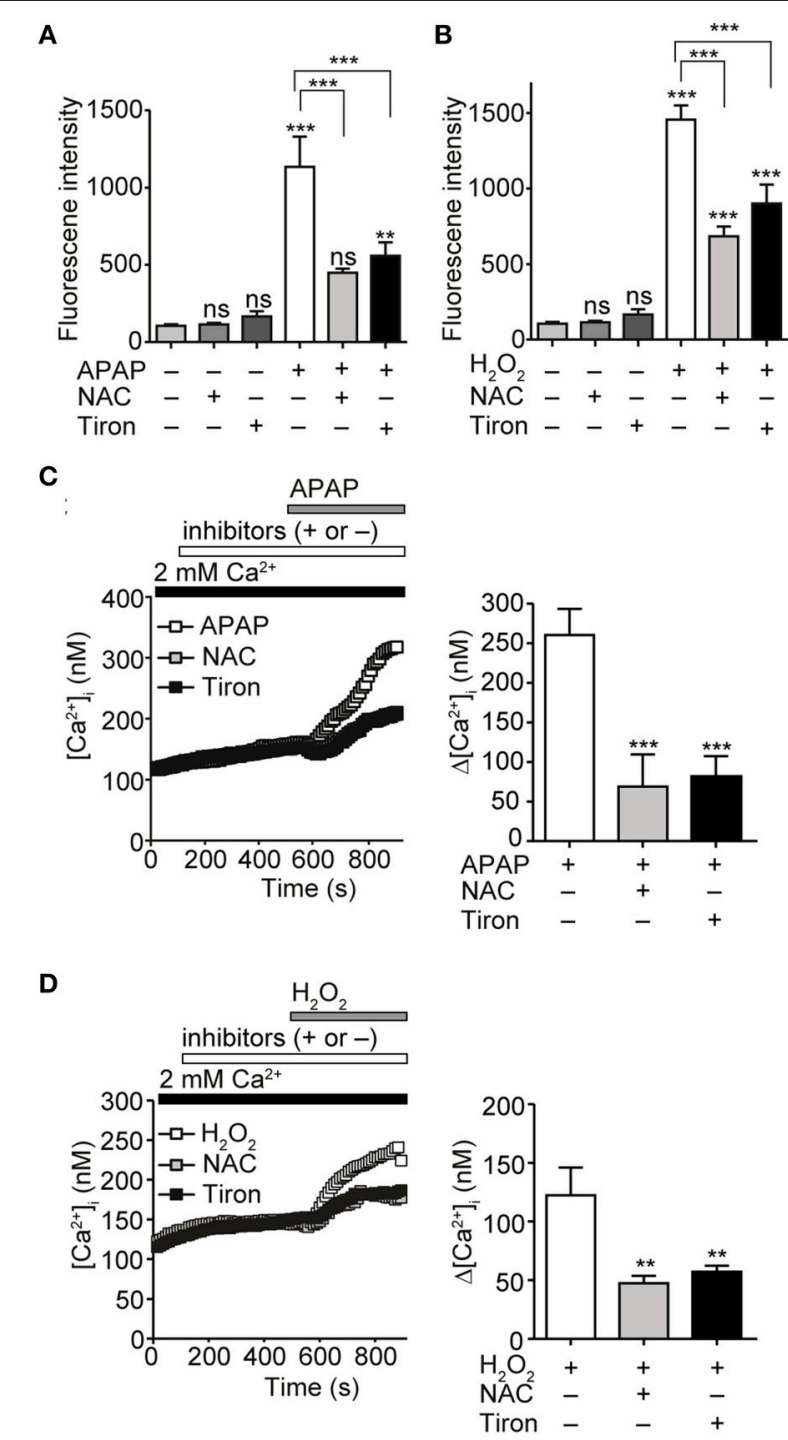

FIGURE 2 | Attenuation of APAP- or $\mathrm{H}_{2} \mathrm{O}_{2}$-induced ROS production and $\mathrm{Ca}^{2+}$ responses by ROS scavengers in HepG2 cells. (A) Suppression of ROS levels induced by APAP $(20 \mathrm{mM})$ treatment for $3 \mathrm{~h}$ by either $\mathrm{N}$-acetyl-L-cysteine (NAC) or tiron (1 mM). (B) Suppression of ROS levels induced by $\mathrm{H}_{2} \mathrm{O}_{2}$ treatment ( $1 \mathrm{mM}$ ) for $3 \mathrm{~h}$ by either $\mathrm{NAC}$ or tiron (1 mM). (C) Effects of either NAC or tiron $(1 \mathrm{mM})$ on APAP $(20 \mathrm{mM})$ induced-[ $\left[\mathrm{Ca}^{2+}\right]_{\mathrm{i}}$ responses in HepG2 cells. Average time courses (left) and $\Delta\left[\mathrm{Ca}^{2+}\right]_{i}$ (right) ( $n=24-62)$. (D) Effects of either NAC or tiron (1 mM) on $\mathrm{H}_{2} \mathrm{O}_{2}(1 \mathrm{mM})$ induced-Ca ${ }^{2+}$ entry in HepG2 cells. Average time courses (left) and $\Delta\left[\mathrm{Ca}^{2+}\right]$ (right) ( $n=19-33)$. ROS scavengers are applied for $3 \mathrm{~h}$ before and during APAP or $\mathrm{H}_{2} \mathrm{O}_{2}$ stimulation. Data points are mean \pm SEM. $P \geq 0.05$,

${ }^{* *} P<0.01$, and ${ }^{* \star *} P<0.001$. Differences not statistically significant are labeled as (ns). All data of $\left[\mathrm{Ca}^{2+}\right]_{\mathrm{i}}$ measurements were analyzed by Student's $t$-test, while those of ROS measurements were analyzed by ANOVA and Bonferroni post-hoc.

\section{Characterization of Redox-Sensitive TRP Channels Found in HepG2 using HEK293 Cell System}

The data above suggested a role for ROS in mediating $\left[\mathrm{Ca}^{2+}\right]_{\mathrm{i}}$ increases in response to APAP overdose in HepG2 cells.
TRPV1, TRPV3, TRPV4, TRPC1, TRPC4, TRPC5 (Yoshida et al., 2006), TRPM2 (Hara et al., 2002), TRPM7 (Aarts et al., 2003), and TRPA1 channels (Takahashi et al., 2008) were reportedly activated by $\mathrm{H}_{2} \mathrm{O}_{2}$. Therefore, we hypothesized that these channels might be involved in the aforementioned APAPinduced $\mathrm{Ca}^{2+}$ responses in HepG2 cells. To investigate this, we first examined expression of mRNAs for redox-sensitive TRPV14, TRPC1, TRPC4, TRPC5, TRPM2, TRPM7, and TRPA1 channels by RT-PCR in HepG2 cells. As shown in Figure 3A, RNAs encoding TRPV1-4, TRPC1, TRPM2, and TRPM7 were detected in HepG2 cells. Next, we tested whether 20 mM APAP activates recombinant ROS-sensitive TRP channels expressed in HEK293 cells. APAP, at $20 \mathrm{mM}$, evoked $\left[\mathrm{Ca}^{2+}\right]_{i}$ responses in HEK293 cells expressing TRPV1, TRPC1, TRPM2, TRPM7, or TRPA1 but not in cells expressing TRPV2, TRPV3, TRPV4, TRPC4, or TRPC5 (Figure 3B). In contrast, all TRP channels except TRPC4 responded to $\mathrm{H}_{2} \mathrm{O}_{2}$ (Figure 3C), as previously reported (Hara et al., 2002; Aarts et al., 2003; Yoshida et al., 2006; Takahashi et al., 2008). These results illustrate the sensitivity of HEK293 cells expressing TRPV1, TRPC1, TRPM2, TRPM7, and TRPA1 to both APAP and $\mathrm{H}_{2} \mathrm{O}_{2}$. Though, TRPA1, among all the channels, showed the highest $\mathrm{Ca}^{2+}$ responses to APAP, its molecular expression had not, as noted above, been detected in HepG2 cells. This was confirmed by comparing HepG2 with a positive control, demonstrating TRPA1 mRNA expression in WI38 human lung fibroblast cells (Supplementary Figure 1A), which express functional TRPA1 (Jaquemar et al., 1999; Hu et al., 2010; Kozai et al., 2014a). In addition, we found that $100 \mu \mathrm{M}$ AITC, a TRPA1 agonist (Jordt et al., 2004), failed to elicit a $\mathrm{Ca}^{2+}$ response in HepG2 cells (Supplementary Figure 1B). Therefore, TRPV1 is the most responsive to APAP, among the recombinant TRPs that are found being expressed in HepG2 cells. Overall, these results raise a possibility that redox-sensitive TRPV1, TRPC1, TRPM2, and TRPM7 contribute to the APAP-induced $\mathrm{Ca}^{2+}$ responses in HepG2 cells.

\section{APAP-Evoked $\mathrm{Ca}^{2+}$ Entry and ROS Production in HepG2 Cells are Mediated by TRPV1, TRPC1, TRPM2, and TRPM7}

To characterize involvement of endogenous redox-sensitive TRPV1, TRPC1, TRPM2, and TRPM7 in the APAP-induced $\mathrm{Ca}^{2+}$ responses in HepG2 cells, we employed blockers for these TRP channels. These were capsazepine (CPZ), 2-aminoethyl diphenylborinate (2-APB), clotrimazole (CTZ), and 2-(12hydroxydodeca-5,10-diynyl)-3,5,6-trimethyl-p-benzoquinone (AA861), previously shown to block recombinant TRPV1 (McIntyre et al., 2001), TRPC1 (Lievremont et al., 2005), TRPM2 (Kheradpezhouh et al., 2014), and TRPM7 (Chen et al., 2010), respectively.

For $\left[\mathrm{Ca}^{2+}\right]_{\mathrm{i}}$ measurements, HepG2 cells were pretreated with $10 \mu \mathrm{M} \mathrm{CPZ}, 100 \mu \mathrm{M} 2-\mathrm{APB}, 50 \mu \mathrm{M}$ CTZ, or $10 \mu \mathrm{M}$ AA861 for $6 \mathrm{~min}$, then with APAP $(20 \mathrm{mM})$ or $\mathrm{H}_{2} \mathrm{O}_{2}(1 \mathrm{mM})$. $\left[\mathrm{Ca}^{2+}\right]_{\mathrm{i}}$ increases induced by APAP in HepG2 cells were significantly lower if cells were also pretreated with CPZ, 2-APB, CTZ, or AA861 (Figure 4A). Strikingly, CPZ and 2-APB exerted relatively strong, however insignificantly inhibition among the 
A

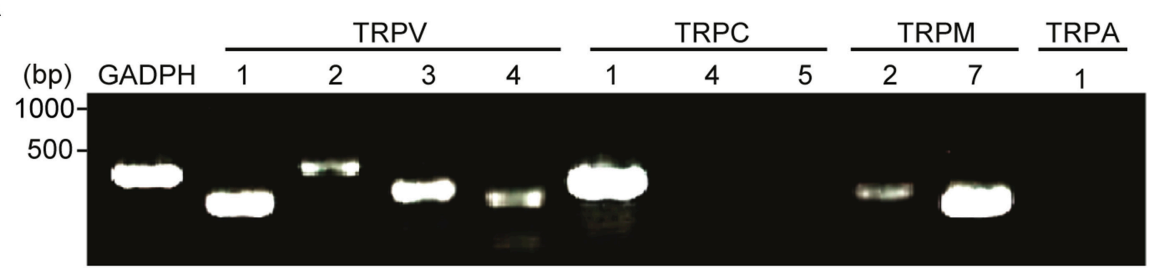

B
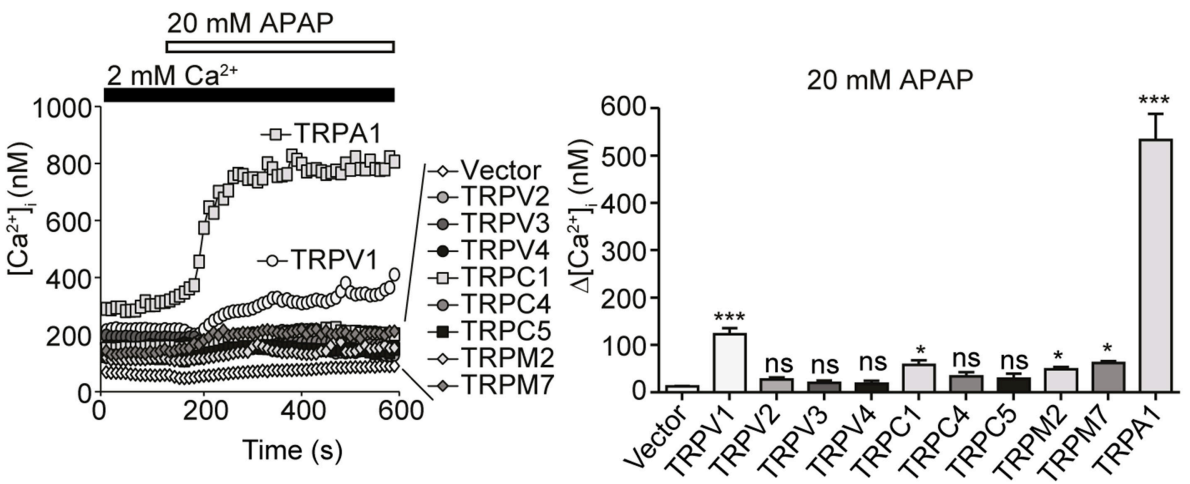

C
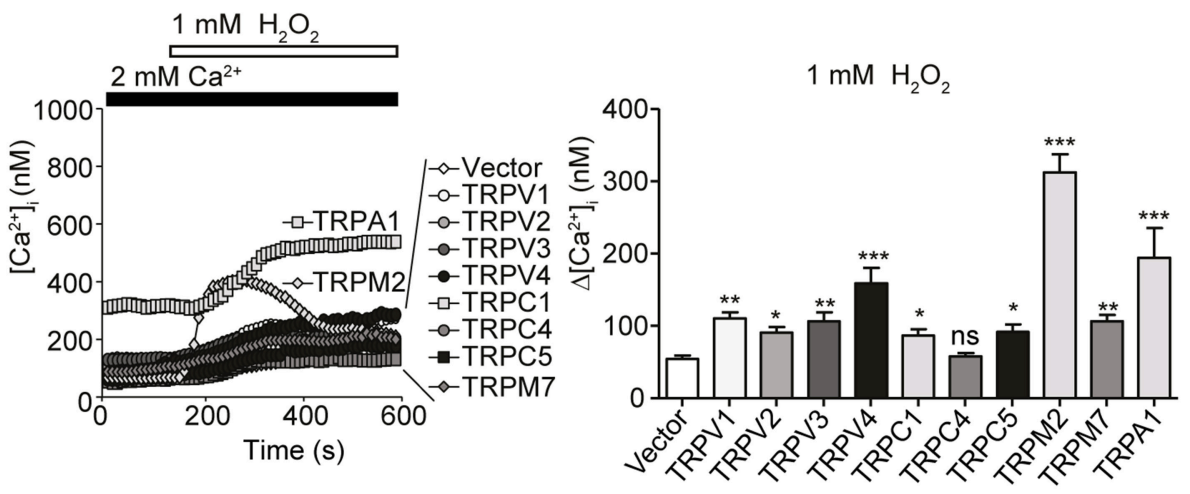

FIGURE 3 | Expression of redox-sensitive TRP channels in HepG2 cells and their responses when expressed in HEK293 cells. (A) Expression of redox-sensitive TRP channel mRNAs [TRPV1-4, TRPC1, TRPC4, TRPC5, TRPM2, TRPM7, TRPA1, and glyceraldehyde-3-phosphate dehydrogenase (GAPDH)] detected by RT-PCR in total RNA isolated from HepG2 cells. Specific PCR primers used are listed in Table 1. (B,C) $\left[\mathrm{Ca}^{2+}\right]_{\mathrm{i}}$ responsesevoked by $20 \mathrm{mM}$ APAP (B) or $1 \mathrm{mM} \mathrm{H}_{2} \mathrm{O}_{2}$ (C) in HEK293 cells expressing human TRPV1, human TRPV2, human TRPV3, human TRPV4, mouse TRPC1, mouse TRPC4 $\beta$, mouse TRPC5, human TRPM2, human TRPM7, human TRPA1, or vector. Average time courses (left) and $\Delta\left[\mathrm{Ca}^{2+}\right]_{\mathrm{i}}$ (right) $(n=16-64)$. Data points are mean $\pm \mathrm{SEM}$. $P \geq 0.05,{ }^{*} P<0.05$, ${ }^{\star \star} P<0.01$, and ${ }^{\star \star \star} P<0.001$ compared to vector. Differences not statistically significant are labeled as (ns). All data were analyzed by Student's $t$-test.

blockers employed. Similar inhibition was observed against $\left[\mathrm{Ca}^{2+}\right]_{\mathrm{i}}$ increases induced by $1 \mathrm{mM} \mathrm{H}_{2} \mathrm{O}_{2}$ (Figure 4B). Levels of intracellular ROS at $3 \mathrm{~h}$ after incubation of HepG2 with either APAP (Figure 4C) or $\mathrm{H}_{2} \mathrm{O}_{2}$ (Figure 4D) were also significantly suppressed by pretreatment with the four TRP channel blockers. Treatment of HepG2 cells with TRP channel blockers alone did not affect ROS levels (Supplementary Figure 1C). Thus, native TRPV1, TRPC1, TRPM2, and TRPM7 are likely to be involved in the APAP-induced oxidative stress and $\mathrm{Ca}^{2+}$ overload we observed in HepG2 cells.

To confirm this interpretation, knockdown of individual channels was accomplished by treating HepG2 cells with a small interfering RNA (siRNA) duplex targeting either TRPV1,
TRPC1, TRPM2, or TRPM7. Reduced mRNA (Figure 5A) and protein levels (Figure 5B, Supplementary Figure 1D) of the corresponding TRPV1, TRPC1, TRPM2, and TRPM7 channels were observed with specific siRNA, as compared with control siRNA (siScramble). Importantly, HepG2 cells transfected with siTRPV1 or siTRPC1 showed a significant reduction in APAPor $\mathrm{H}_{2} \mathrm{O}_{2}$-induced $\mathrm{Ca}^{2+}$ influx (Figures 5C,D, respectively) and intracellular ROS levels (Figures 5E,F, respectively). This effect was greater than that in HepG2 cells transfected with siTRPM2 or siTRPM7. No significant changes in ROS levels were found in unstimulated HepG2 cells transfected with each of these siRNAs, as compared with siScramble (Supplementary Figure 1E). These results suggest that TRPV1 and TRPC1 were more involved in 


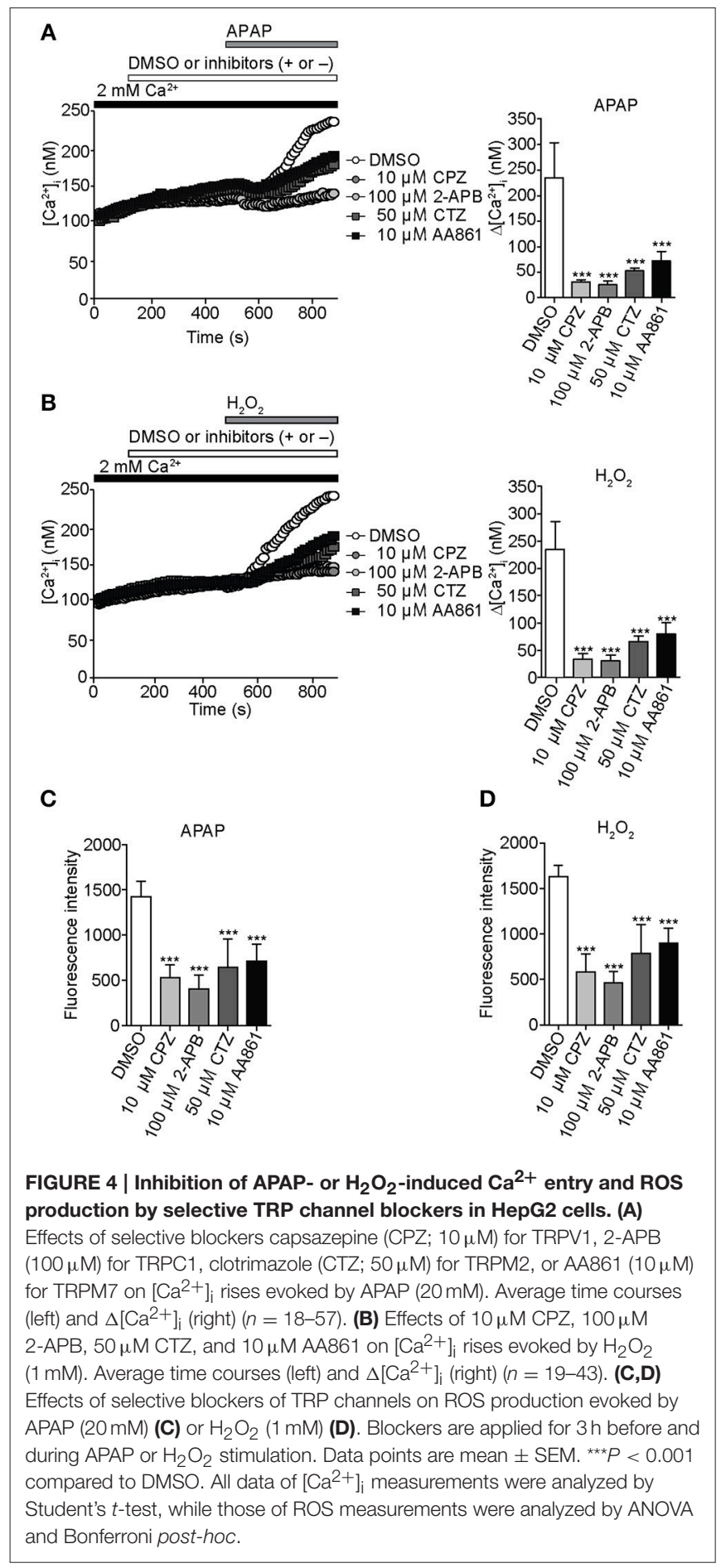

APAP-induced oxidative stress and $\mathrm{Ca}^{2+}$ overload in HepG2 cells than were TRPM2 and TRPM7.

\section{Apoptosis is Involved in APAP or $\mathrm{H}_{2} \mathrm{O}_{2}$-Induced HepG2 Cell Death}

Acetaminophen has been reported to induce cell death by apoptosis (Boulares et al., 2002). HepG2 cells were cultured in serum-free DMEM and treated with different doses of APAP $\left(5,15\right.$, and $20 \mathrm{mM}$; Figure 6A) or $\mathrm{H}_{2} \mathrm{O}_{2}(0.25,0.5$, and $1 \mathrm{mM}$; Figure 6B) for $24 \mathrm{~h}$. A dose dependent decrease in HepG2 cell viability was shown by trypan blue exclusion. Similar dose dependent decreases in cell viability were also observed with 6 and $12 \mathrm{~h}$ treatments with APAP (Supplementary Figure 2A) or $\mathrm{H}_{2} \mathrm{O}_{2}$ (Supplementary Figure 2B). HepG2 cell death, assessed by Hoechst33342/PI staining, indicated a significant increase in the number of PI-positive dead cells (red) after incubation with $20 \mathrm{mM}$ APAP or $1 \mathrm{mM} \mathrm{H}_{2} \mathrm{O}_{2}$ for $24 \mathrm{~h}$ (Figure 6C).

Internucleosomal DNA fragmentation and caspase 3/7 activation represent essential steps in the apoptotic cell death (Denault and Salvesen, 2002). HepG2 cells treated with APAP or $\mathrm{H}_{2} \mathrm{O}_{2}$ for $24 \mathrm{~h}$ showed a dose dependent increase in DNA fragmentation compared with control cells (Figures 6D,E, respectively). To examine whether HepG2 cell death elicited by APAP or $\mathrm{H}_{2} \mathrm{O}_{2}$ occurs via apoptosis, we measured the caspase 3/7 activity. There was an increase in caspase 3/7 activity in HepG2 cells proportional to the duration of treatment with either APAP $(20 \mathrm{mM})$ or $\mathrm{H}_{2} \mathrm{O}_{2}(1 \mathrm{mM})$ (Figure $6 \mathrm{~F}$, Supplementary Figure $2 \mathrm{C})$. These results suggest that APAP and $\mathrm{H}_{2} \mathrm{O}_{2}$ induce apoptotic death of HepG2 cells.

We next assessed involvement of ERK, JNK or P38 MAPK pathways in APAP-induced HepG2 cell death. These pathways regulate the cell cycle, differentiation and growth as well as apoptosis (Tidyman and Rauen, 2009) and the mitochondrial permeability transition (MPT; Qian et al., 1997). For these experiments, we employed the specific inhibitors W-7 for $\mathrm{Ca}^{2+}$ calmodulin, cyclosporine A (CsA) for MPT, U0126 for ERK, SP600125 for JNK, and SB203580 for P38 MAPK. Compared with untreated cells, there was no significant cell death in HepG2 cells treated with $1 \mu \mathrm{M} \mathrm{W}-7,4 \mu \mathrm{M}$ CsA, or $20 \mu \mathrm{M}$ of either U0126, SP600125 or SB203580 (Supplementary Figure 2D). HepG2 cells treated with some of these inhibitors were partially protected from APAP compared to the cells that were treated only with APAP. However, at $20 \mu \mathrm{M}$, U0126 or SB203580 did not significantly decrease APAP-induced cell death (Figure 6G, Supplementary Figure 2E). This finding suggests that APAP induced apoptosis in HepG2 cells was via activation of JNK and MPT, while the p38 and the ERK MAPK pathways did not contribute.

To investigate the correlations among ROS levels, $\left[\mathrm{Ca}^{2+}\right]_{\mathrm{i}}$ elevation and cell death, we examined effects of ROS scavengers on HepG2 cell viability in the presence of APAP or $\mathrm{H}_{2} \mathrm{O}_{2}$. Preincubation of HepG2 cells with of either NAC or tiron ( $1 \mathrm{mM}$ ) for $3 \mathrm{~h}$ prior to treatment with APAP or $\mathrm{H}_{2} \mathrm{O}_{2}$ significantly improved cell viability (Figure 7A) and reduced the number of PI-positive cells (red) (Figure 7B, Supplementary Figure 3A). The ROS scavengers alone showed no significant effects on cell viability or PI-staining in HepG2 cells (Supplementary Figures $4 \mathrm{~A}, \mathrm{~B})$.

Strikingly, pretreatment of HepG2 cells with TRP channel blockers ( $1 \mu \mathrm{M}$ of either CPZ, 2-APB, CTZ, or AA861) for $3 \mathrm{~h}$ prior to treatment with APAP or $\mathrm{H}_{2} \mathrm{O}_{2}$ significantly improved cell viability (Figure 7C) and reduced the numbers of PI-positive cells (red) (Figure 7D, Supplementary Figure 3B). Similar results 
A

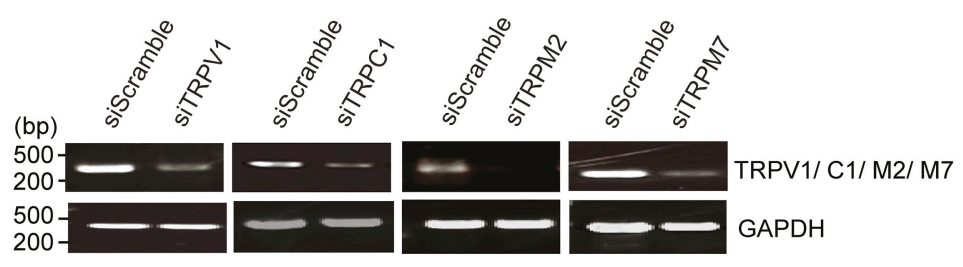

B

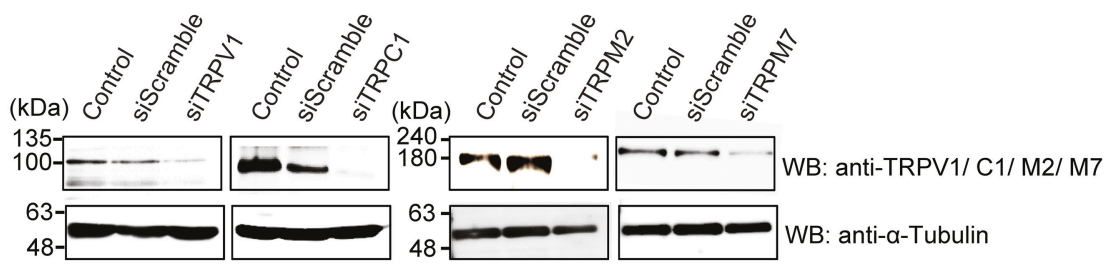

C

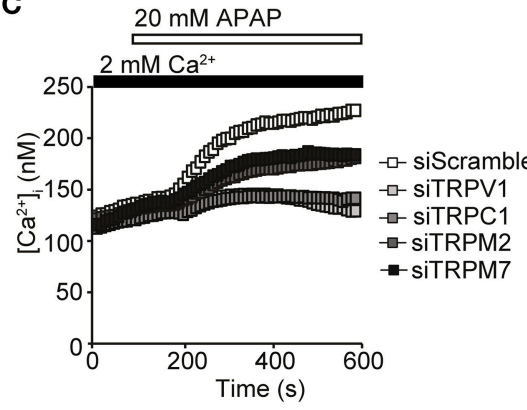

D

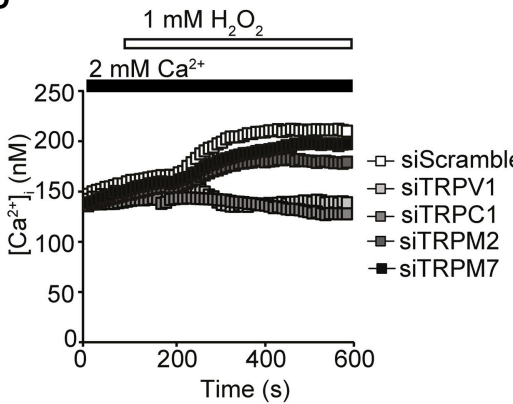

E

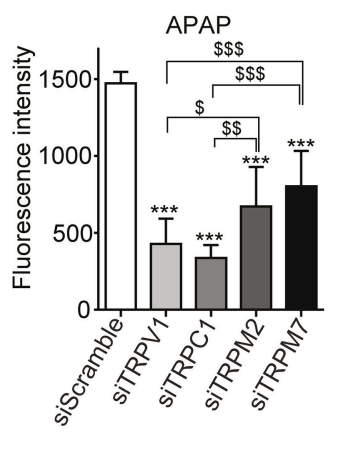

$\mathbf{F}$

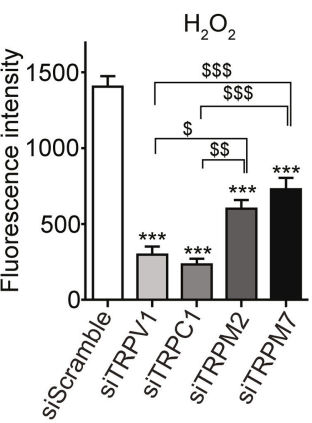

FIGURE 5 | Inhibition of APAP- or $\mathrm{H}_{2} \mathrm{O}_{2}$-induced $\mathrm{Ca}^{2+}$ responses and ROS production by siRNA-mediated knockdown of either TRPV1, TRPC1, TRPM2, or TRPM7 channel in HepG2 cells. (A) Effects of specific siRNA (siTRP) on channels of TRPV1, TRPC1, TRPM2, and TRPM7 mRNA levels detected by RT-PCR. GAPDH is used as a positive control. (B) Effects of siTRPV1, siTRPC1, siTRPM2, and siTRPM7 on levels of corresponding proteins detected by western blot. An anti- $\alpha$-tubulin is used as a loading control. (C,D) $\left[\mathrm{Ca}^{2+}\right]_{i}$ changes induced by $20 \mathrm{mM}$ APAP (C) or $1 \mathrm{mM} \mathrm{H}_{2} \mathrm{O}_{2}$ (D) in cells treated with siTRPM2, siTRPM7, siTRPV1, siTRPC1, or siScramble. Average time courses (left) and $\Delta\left[\mathrm{Ca}^{2+}\right]_{i}$ (right) $(n=50-125)$. (E,F) Inhibitory effects of siTRPM2, siTRPM7, siTRPV1, siTRPC1, or siScramble on ROS produced by $20 \mathrm{mM}$ APAP (E) or $1 \mathrm{mM} \mathrm{H}_{2} \mathrm{O}_{2}$ for $3 \mathrm{~h}$ (F). Data points are mean \pm SEM. ${ }^{\star} P<0.05,{ }^{\star \star} P<0.01$ and ${ }^{\star \star \star} P<0.001$ compared to siScramble. ${ }^{\$} P<0.05, \$ \$ P<0.01$, and $\$ \$ \$ P<0.001$ compared to siTRPV1 or siTRPC1. All data of $\left[\mathrm{Ca}^{2+}\right]_{\mathrm{i}}$ measurements were analyzed by Student's $t$-test, while those of ROS measurements were analyzed by ANOVA and Bonferroni post-hoc.

were observed after siRNA-mediated knockdown of TRPV1, TRPC1, TRPM2, and TRPM7 (Figures 7E,F, Supplementary Figure 3C). Being consistent with the contribution of TRPV1 and TRPC1 to APAP-induced $\mathrm{Ca}^{2+}$ entry, the siRNAs for TRPV1 and TRPC1 worked more efficiently than those of the others, a finding consistent with measurements of $\mathrm{Ca}^{2+}$ responses (Figures 5C,D) and ROS levels (Figures 5E,F). The channel blockers or siRNAs alone did not significantly affect cell viability and number of PI-positive cell compared to untreated HepG2 cells (Supplementary Figures 4C-F).

Increases in caspase 3/7 activity and intracellular cytochrome c release, induced by APAP or $\mathrm{H}_{2} \mathrm{O}_{2}$, were also ameliorated by pretreatment with ROS scavengers ( $1 \mathrm{mM}$ of either NAC or tiron; Figures $\mathbf{8 A , B})$, selective TRP channel blockers $(1 \mu \mathrm{M}$ 


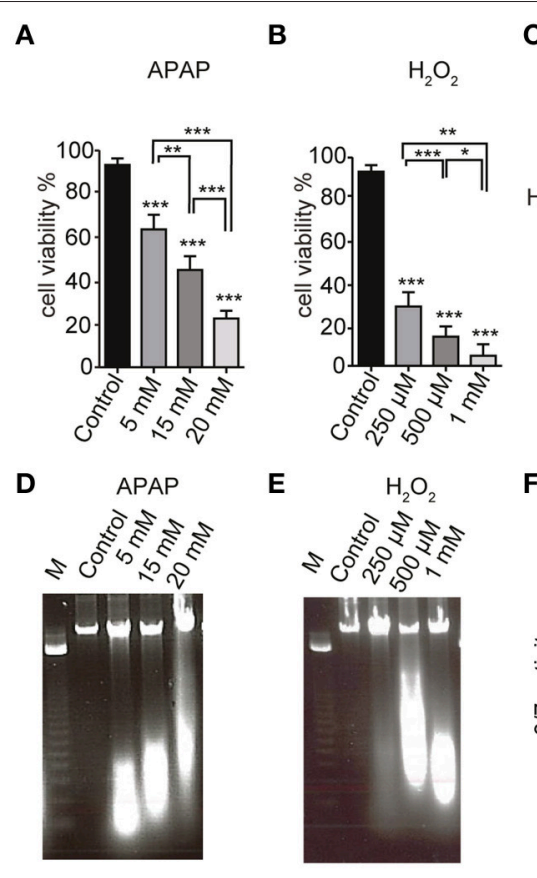

C
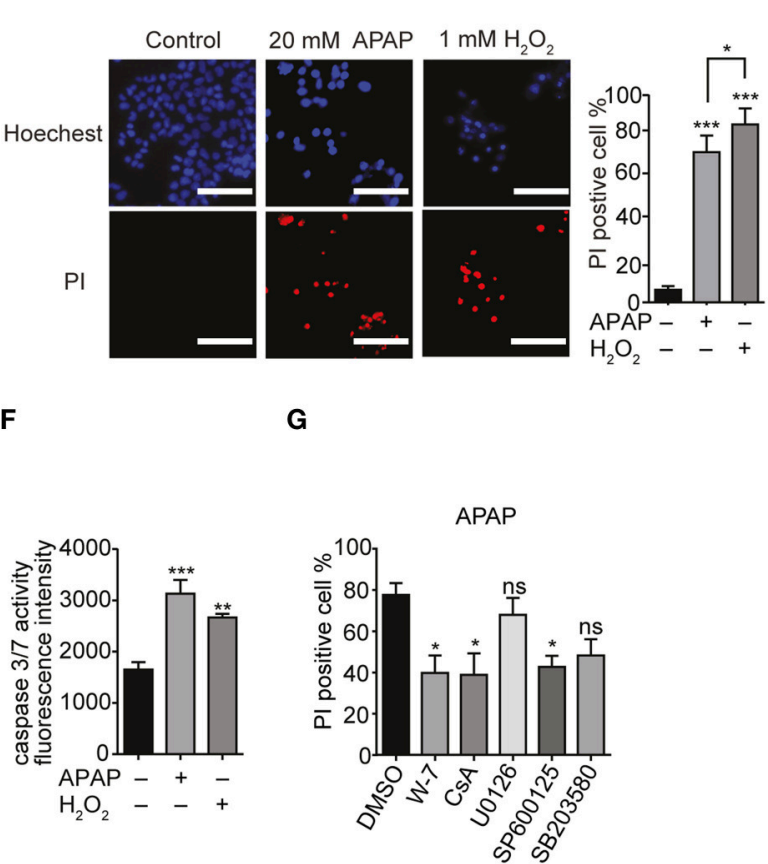

FIGURE 6 | APAP-induced HepG2 cell death. (A,B) Dose dependence of viabilities of HepG2 cell treated with APAP (A) or $\mathrm{H}_{2} \mathrm{O}_{2}$ (B) for $24 \mathrm{~h}$. Cell viability is presented as percentage of viable cells in trypan blue exclusion assay. (C) HepG2 cell death upon exposure to $20 \mathrm{mM}$ APAP or $1 \mathrm{mM} \mathrm{H}_{2} \mathrm{O}_{2}$ for $24 \mathrm{~h}$. Hoechst33342and propidium iodide (PI)-staining were visualized by fluorescence microscopy. Scale bar, $100 \mu \mathrm{m}$. (D,E) DNA fragmentation in HepG2 cells. Cells were exposed for $24 \mathrm{~h}$ to $\operatorname{APAP}$ (D) $(5,15$, and $20 \mathrm{mM})$ or $\mathrm{H}_{2} \mathrm{O}_{2}$ (E) $(250 \mu \mathrm{M}, 500 \mu \mathrm{M}$, and $1 \mathrm{mM})$. M is the DNA marker. (F) Caspase $3 / 7$ activity in HepG2 cells stimulated with 20 mM APAP or $1 \mathrm{mM} \mathrm{H}_{2} \mathrm{O}_{2}$ for $24 \mathrm{~h}$. (G) Effects of either $\mathrm{Ca}^{2+}$-calmodulin antagonist $(\mathrm{W}-7$; $1 \mu \mathrm{M})$, cyclosporine A (CsA; $\left.4 \mu \mathrm{M}\right)$, or different MAPK-specific inhibitors (U0126, SP600125 and SB203580; $20 \mu \mathrm{M}$ ) on HepG2 cell death induced by APAP for $24 \mathrm{~h}$ in Hoechst33342- and PI-staining assays. Data points are mean \pm SEM. $P \geq 0.05$, ${ }^{\star} P<0.05,{ }^{\star \star} P<0.01$, and ${ }^{\star \star \star} P<0.001$ compared to DMSO or control. Differences not statistically significant are labeled as (ns). All data were analyzed by ANOVA and Bonferroni post-hoc.

of either CPZ, 2-APB, CTZ, or AA861; Figures 8C,D) as well as by siRNA-mediated knockdown of TRPV1, TRPC1, TRPM2, or TRPM7 (Figures 8E,F; Supplementary Figures 4G-J). These results suggest that APAP-induced HepG2 cell apoptosis was more dependent on TRPV1 and TRPC1 than on TRPM2 and TRPM7, when assessed by $\mathrm{Ca}^{2+}$ entry, ROS levels, and mitochondrial membrane depolarization.

\section{Involvement of Cysteine Residues in Redox and APAP Sensing of TRPV1 and TRPC1}

An intriguing question is the mechanism that explains the relative importance of TRPV1 and TRPC1 compared with other TRPs. It has been reported that free thiol groups of cysteine residues are among the major targets of oxidation and electrophiles in proteins. This is also the case for TRP channels; oxidants and electrophiles induce their activation (Yoshida et al., 2006; Takahashi et al., 2008). To examine involvements of cysteine residues of TRPV1 and TRPC1 in their APAP responsiveness, we incubated permeabilized HEK293T cells transfected with GFP-tagged TRPV1 or Flag-tagged TRPC1 with DTNB-2Bio, which reacts with free thiol groups and can be purified by avidin-based affinity purification (Yoshida et al., 2006; Takahashi et al., 2008). DTNB-2Bio was incorporated into TRPV1 (Figure 9B) and TRPC1 (Figure 9C), and this was blocked by pretreatment with $20 \mathrm{mM}$ APAP. In contrast, no blockade by APAP was detected for DTNB-2Bio incorporation into TRPV4, which had shown only a minor contribution to APAP-induced responses, as compared with TRPV1 and TRPC1 (Figure 9D). Thus, the action of APAP via the modification target cysteine residues may at least in part account for the important roles of TRPV1 or TRPC1 in APAP-induced responses in human hepatoma cells.

\section{GSH Depletion Modulates Sensitivity of $\mathrm{Ca}^{2+}$ Influx and Cell Death to APAP in HepG2 Cells}

In addition to those of ROS, glutathione (GSH) levels serve as pivotal regulators of cellular redox status. Previous studies showed that intracellular GSH suppressed oxidative stressinduced TRPM2 activation and $\mathrm{Ca}^{2+}$ entry in DRG neurons (Nazıroğlu et al., 2011). It is, therefore, important to study the role of GSH in suppressing APAP-induced ROS increases, $\mathrm{Ca}^{2+}$ overload via TRP channels, and cell death in HepG2 cells. Moreover, serum deprivation induces excess ROS production linked to depletion of intracellular GSH (Pandey et al., 2003). We found that serum deprivation enhanced the $\mathrm{Ca}^{2+}$ responses and cell death induced by $20 \mathrm{mM}$ APAP or $1 \mathrm{mM} \mathrm{H}_{2} \mathrm{O}_{2}$ (Supplementary Figures 5A,B) in HepG2, as compared with that 
A

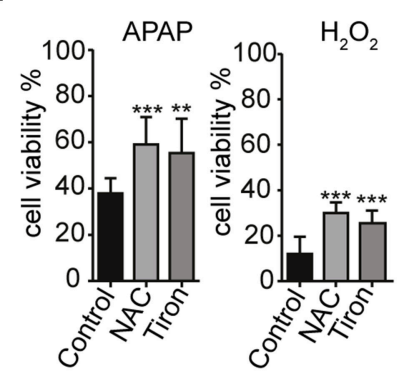

C

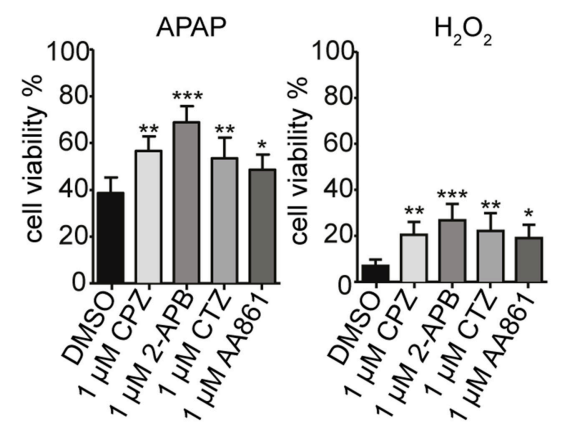

E

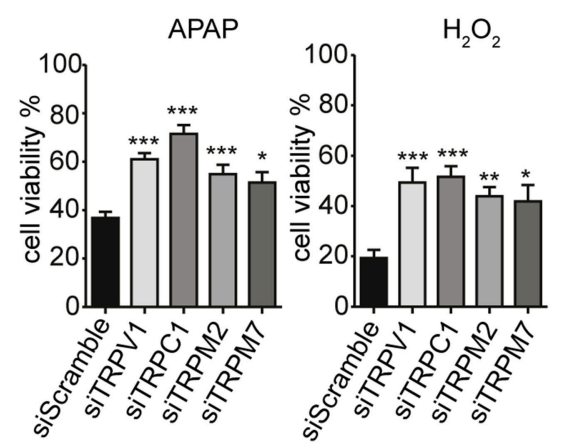

B

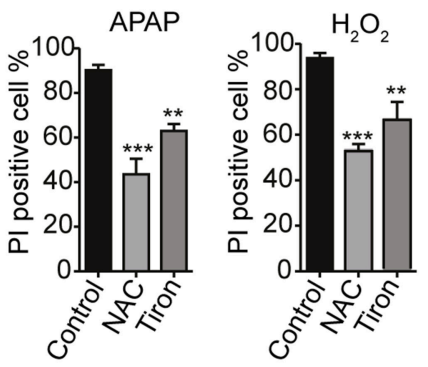

D

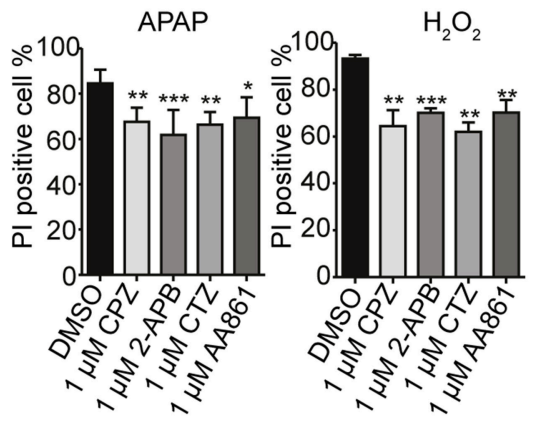

F

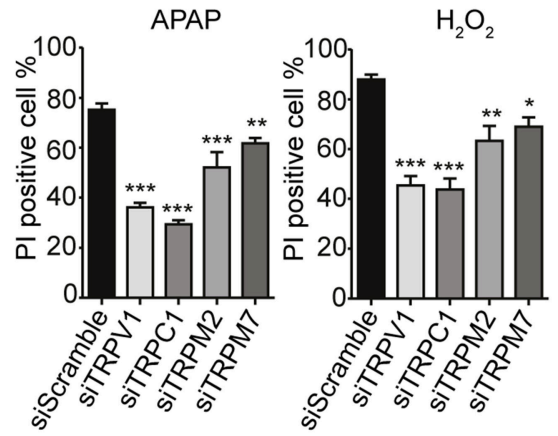

FIGURE 7 | TRPV1, TRPC1, TRPM2, and TRPM7 confer susceptibility to APAP-induced cell death via ROS in HepG2 cells. (A,B) ROS scavengers, NAC and tiron (1 mM), suppressed APAP- or $\mathrm{H}_{2} \mathrm{O}_{2}$-induced losses of cell viability (A) and increases of cell death (B) in HepG2 cells. (C,D) Selective TRP channels blockers, $1 \mu \mathrm{M}$ of either CPZ, 2-APB, CTZ, or AA861 suppressed APAP- or $\mathrm{H}_{2} \mathrm{O}_{2}$-induced losses of cell viability (C) and increases of cell death (D) in HepG2 cells. (E,F) siRNA-mediated knockdown of TRPV1, TRPC1, TRPM2, and TRPM7 suppressed APAP- or $\mathrm{H}_{2} \mathrm{O}_{2}$-induced losses of cell viability (E) and increases of cell death (F) in HepG2 cells. Inhibitors are applied for $3 \mathrm{~h}$ before and during APAP or $\mathrm{H}_{2} \mathrm{O}_{2}$ stimulation. Data points are mean $\pm \mathrm{SEM}$. ${ }^{\star} P<0.05$, ${ }^{\star \star} P<0.01$, and ${ }^{* \star *} P<0.001$ compared to the DMSO, siScramble or control. All data were analyzed by ANOVA and Bonferroni post-hoc.

in normally cultured cells. However, serum deprivation did not affect caspase 3/7 activity (Supplementary Figure 5C), though the GSH content of serum-deprived HepG2 was significantly lower than that of cells cultured normally (Supplementary Figure 5D). Pretreatment of serum-deprived HepG2 with ROS scavengers (NAC or tiron at $1 \mathrm{mM}$ ) for $3 \mathrm{~h}$ significantly reversed APAPor $\mathrm{H}_{2} \mathrm{O}_{2}$-induceddepletion of $\mathrm{GSH}$ content (Supplementary Figure 5E).

Dimethylfumarate (DMF) was previously reported to upregulate antioxidant activities and suppress cell death induced by $\mathrm{H}_{2} \mathrm{O}_{2}$ (Duffy et al., 1998). Treatment of serum-deprived
HepG2 with 50, 100, or $200 \mu \mathrm{M}$ DMF for $24 \mathrm{~h}$ significantly increased GSH content in a dose-dependent manner (Figure 10A). There were no significant changes in cell viability, except for a significant decrease with $200 \mu \mathrm{M}$ DMF (Figure 10B). Intracellular ROS levels $3 \mathrm{~h}$ after incubation of HepG2 with either $20 \mathrm{mM}$ APAP or $1 \mathrm{mM} \mathrm{H}_{2} \mathrm{O}_{2}$ were also significantly reduced by pretreatment with $100 \mu \mathrm{M}$ DMF (Figure 10C). Furthermore, GSH content in HepG2 cells after $24 \mathrm{~h}$ incubation with either APAP or $\mathrm{H}_{2} \mathrm{O}_{2}$ was also significantly higher in cells that had been pretreated with $100 \mu \mathrm{M}$ DMF (Figure 10D). 


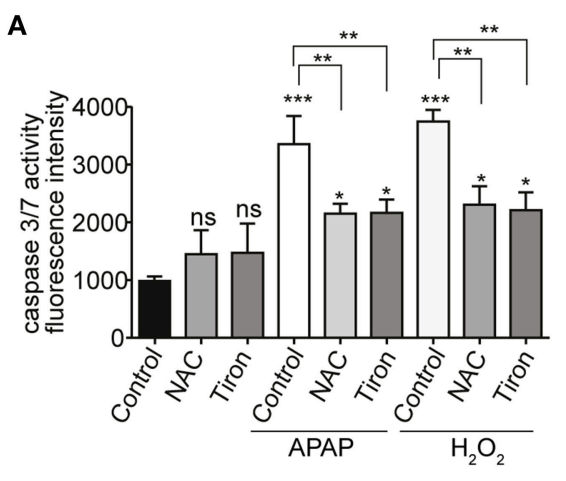

C

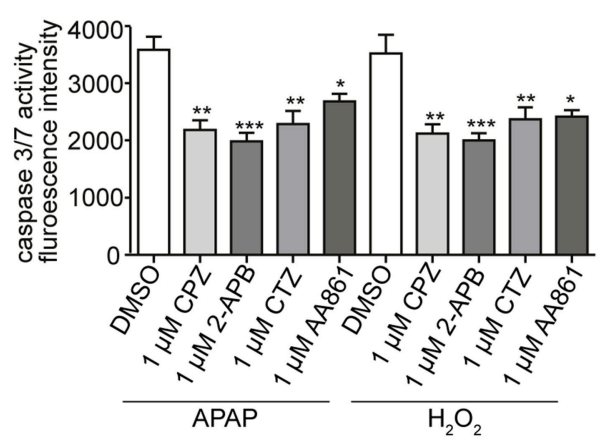

E

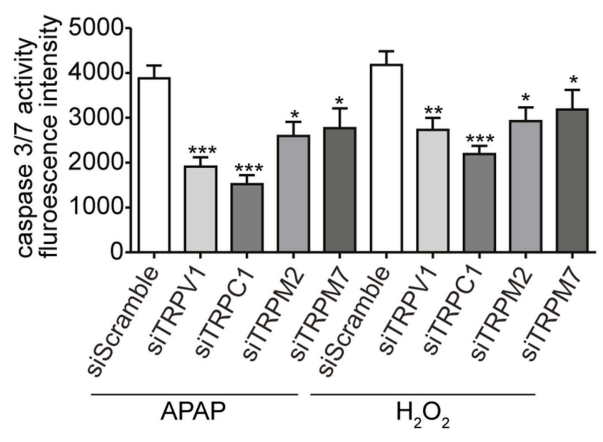

B

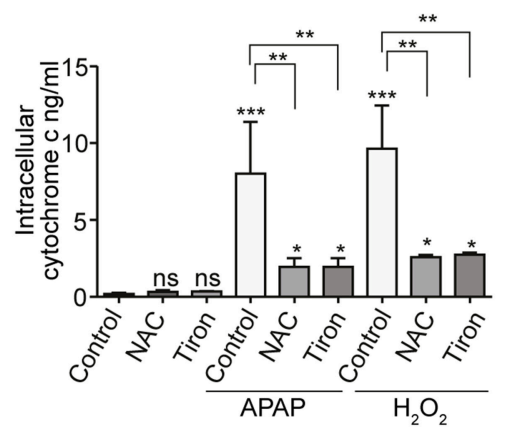

D

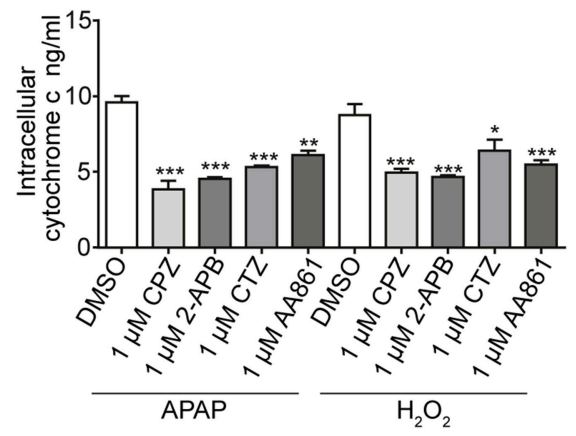

F

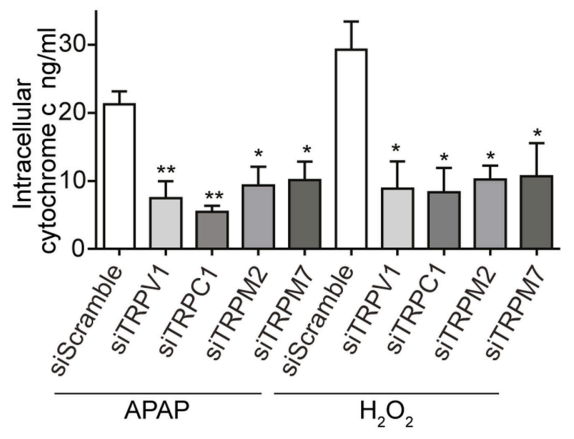

FIGURE 8 | Effects of APAP on the activity of caspase 3/7 and the level of intracellular cytochrome $\mathbf{c}$ in HepG2 cell. (A,B) ROS scavengers, NAC or tiron, (1 mM) suppressed APAP- or $\mathrm{H}_{2} \mathrm{O}_{2}$-induced increases of the activity of caspase 3/7 (A) and the level of intracellular cytochrome c (B) in HepG2 cells. (C,D) Selective $\mathrm{Ca}^{2+}$ channels blockers, $1 \mu \mathrm{M}$ of either CPZ, 2-APB, CTZ, and AA861 suppressed APAP- or $\mathrm{H}_{2} \mathrm{O}_{2}$-induced increases of the activity of caspase $3 / 7$ (C) and the level of intracellular cytochrome c (D) of HepG2 cells. (E,F) siRNA-mediated knockdown of TRPV1, TRPC1, TRPM2, and TRPM7 suppressed APAP- or $\mathrm{H}_{2} \mathrm{O}_{2}$-induced increases of the activity of caspase $3 / 7$ (E) and the level of intracellular cytochrome $c$ (F) in HepG2 cells. Data points are mean \pm SEM. $P \geq 0.05$, ${ }^{*} P<0.05$, ${ }^{* *} P<0.01$, and ${ }^{* \star *} P<0.001$ compared to the DMSO, siScramble or control. Differences not statistically significant are labeled as (ns). All data were analyzed by ANOVA and Bonferroni post-hoc.

Preincubation of serum-deprived HepG2 cells with $100 \mu \mathrm{M}$ DMF for $24 \mathrm{~h}$, followed by pretreatment with $100 \mu \mathrm{M}$ DMF for $6 \mathrm{~min}$, attenuated the $\left[\mathrm{Ca}^{2+}\right]_{\mathrm{i}}$ increases induced by $20 \mathrm{mM}$ APAP or $1 \mathrm{mM} \mathrm{H}_{2} \mathrm{O}_{2}$ (Figure 10E). In addition, DMF attenuated the loss of cell viability (Figure 10F), increase in caspase 3/7 activity (Figure 10G), intracellular cytochrome c levels (Figure 10H), and cell death (Figure 10I) induced by APAP or $\mathrm{H}_{2} \mathrm{O}_{2}$. No significant cytotoxicity was observed when DMF was administrated in combination with APAP as shown in Figure 10. These results support a role for GSH depletion, reversible with
GSH inducer DMF, in APAP-induced oxidative stress, $\mathrm{Ca}^{2+}$ influx, and HepG2 cell death.

\section{Expression and Cellular Localization of Native Redox-Sensitive TRP Channels in the Human Liver}

To confirm the validity of using HepG2 cells as a model system for hepatotoxicity, we conducted histological experiments to obtain definitive evidence that redox sensitive TRP channels are 

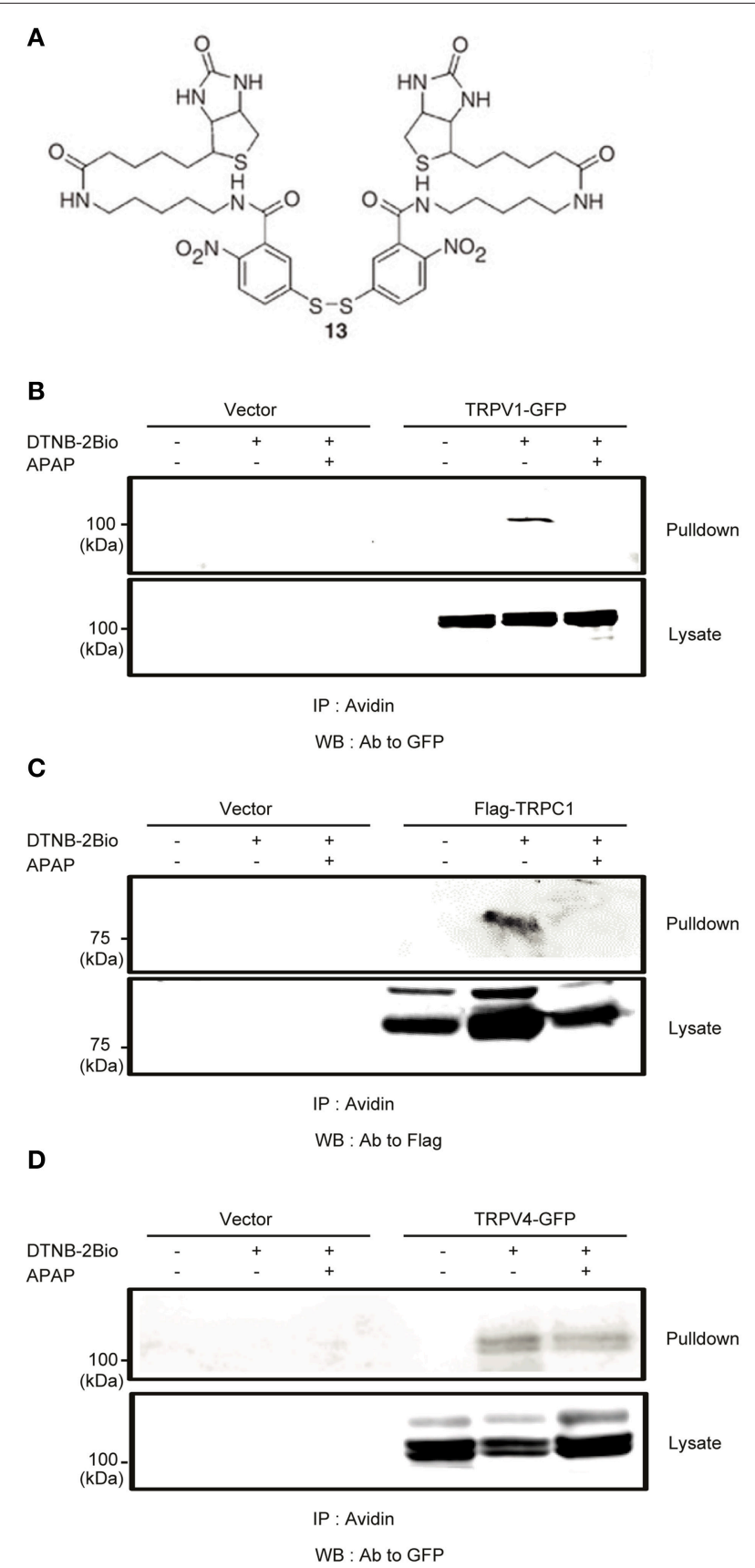

FIGURE 9 | The effects of APAP on the covalent incorporation of DTNB-2Bio in TRPV1, TRPC1, and TRPV4 proteins. (A) Chemical structure of DTNB-2Bio (Yoshida et al., 2006). (B-D) Western blot using an anti-GFP or anti-Flag antibody of avidin-bound fractions (top panel) and total cell lysates (bottom panel) prepared from HEK293T cells which were transfected with EGFP-TRPV1 (B), TRPC1-Flag (C), EGFP-TRPV4 (D), and then incubated with DTNB-2Bio in the presence or absence of $20 \mathrm{mM}$ APAP.

expressed in the human liver. Expression profiles of TRPV14, TRPC1, TRPC4, TRPC5, TRPM2, TRPM7, and TRPA1 were analyzed using PCR in CDNA of normal human liver. TRPV1, TRPC1, TRPM2, TRPM7, and TRPA1 were expressed (Figure 11A).
In situ hybridization of normal human liver sections with antisense probes yielded strong staining for TRPV1, TRPC1, TRPM2, and TRPM7, localized in the nuclei of hepatocytes and Kupffer cells (Figure 11B). The sinusoidal endothelial lining and Kupffer cells were also positive for TRPA1 expression but a lower level, while hepatocytes were negative for this channel (Figure 11B). No hybridization signal was observed with sense probes applied as negative controls (Figure 11B). Recombinant TRPV1, TRPC1, TRPM2, TRPM7, and TRPA1 transcripts were intensely labeled mainly in the nucleus of HEK293T cells (Supplementary Figures 6A-E). RNA transcripts of these TRPs, except for TRPA1, were expressed in HepG2 cells (Supplementary Figures 6A-E).

\section{DISCUSSION}

In this study, we found that APAP overdose elicited ROS production, $\left[\mathrm{Ca}^{2+}\right]_{\mathrm{i}}$ increases, and GSH depletion triggering HepG2 cell death. All responses were markedly reduced by pretreatment with the ROS scavengers, NAC or tiron, or with the GSH inducer DMF. In HepG2 cells, expression of redoxsensitive TRP channels including TRPV1, TRPC1, TRPM2, and TRPM7 was observed. Suppression of TRP channels, particularly, TRPV1 and TRPC1, with channel blockers and siRNAs in terms of function and expression, respectively, substantially reduced APAP-induced ROS formation, $\mathrm{Ca}^{2+}$ influx, and cell death, as summarized in Figure 12. Additionally, in situ hybridization analysis of normal human liver sections showed that transcripts for TRPV1, TRPC1, TRPM2, and TRPM7 channels were primarily localized to hepatocytes and Kupffer cells, while mRNA for TRPA1 was visible, to a lesser extent, in Kupffer cells and sinusoidal endothelium but was absent in hepatocytes.

Earlier reports described the presence of TRPV1-4, TRPC1, and TRPM7 mRNAs but not TRPC4 and TRPC5 in HepG2 cells (Vriens et al., 2004; El Boustany et al., 2008). Other studies showed expression of the TRPM7 channel in rat HSCT6 hepatic stellate, RLC-18 and WIF-B hepatoma cells (Lam et al., 2012; Liu et al., 2012) and of the TRPC1 channel in rat H4-IIE hepatoma cells (Chen and Barritt, 2003). In addition, our study newly reveals, by RT-PCR and in situ hybridization, the existence of TRPM2 mRNA in HepG2 cells. Furthermore, this is the first in situ hybridization analysis to show localization and distribution of TRPV1, TRPC1, TRPM2, and TRPM7 transcripts in the hepatocyte of human liver. Regarding functional expression, HEK293 cells heterologously expressing TRPV1, TRPC1, TRPM2, or TRPM7 responded well to $\mathrm{H}_{2} \mathrm{O}_{2}$, in agreement with previous reports (Hara et al., 2002; Aarts et al., 2003; Yoshida et al., 2006; Salazar et al., 2008), and as well to APAP as indicated by increased $\mathrm{Ca}^{2+}$ entry. In contrast, HEK293 cells expressing TRPV2, TRPV3, TRPV4, TRPC4, or TRPC5 failed to respond to APAP. Such differences are presumably due to structural variations among various TRP channel subfamily members (Figure 3). Interestingly, it has been reported that TRPV subunits can assemble into hetero-oligomeric channel complexes, for example, between TRPV1 and TRPV2 (Hellwig et al., 2005) or TRPV1 and TRPV3 (Smith et al., 2002). Therefore, 


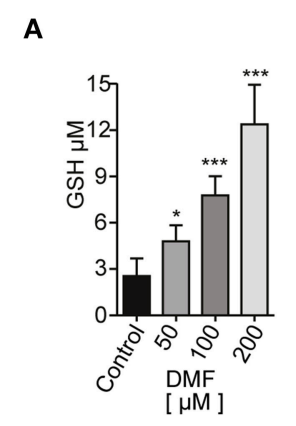

B C

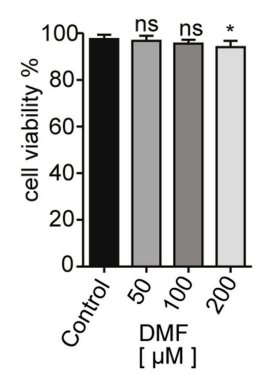

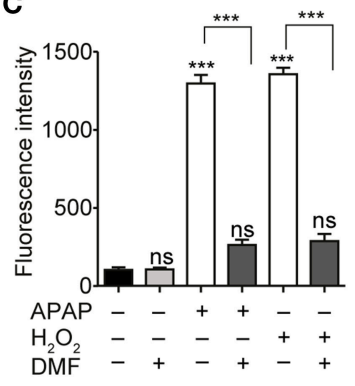

D

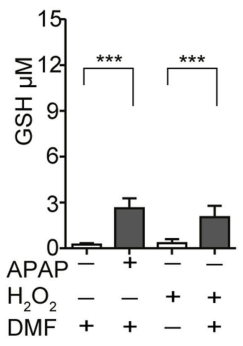

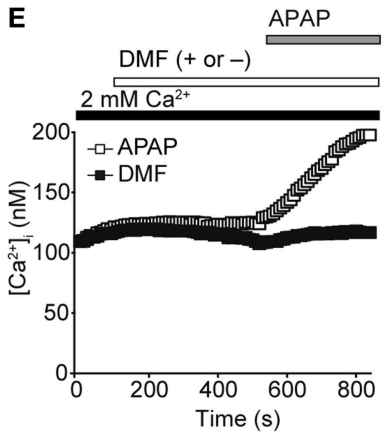

$\mathbf{F}$

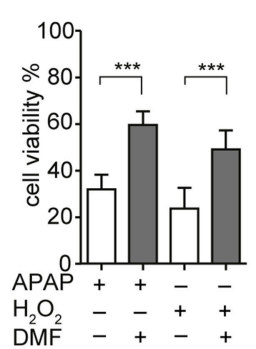

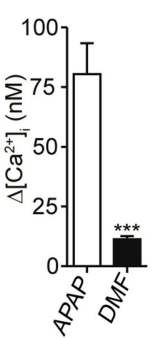

G
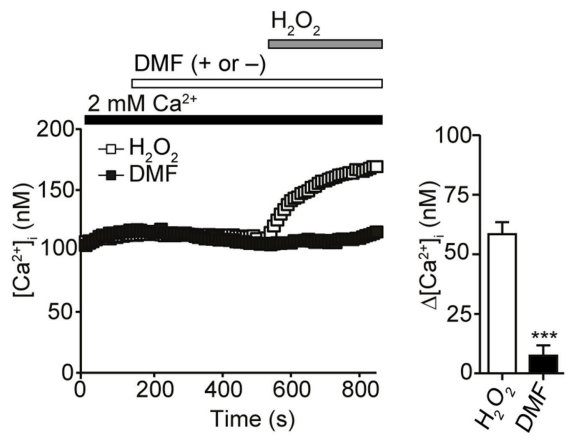

H
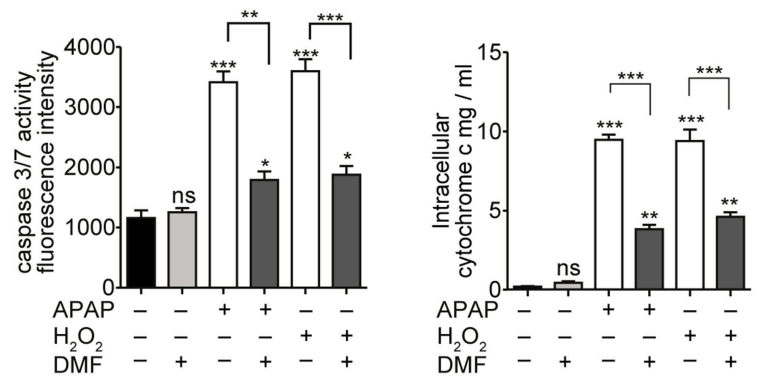

I
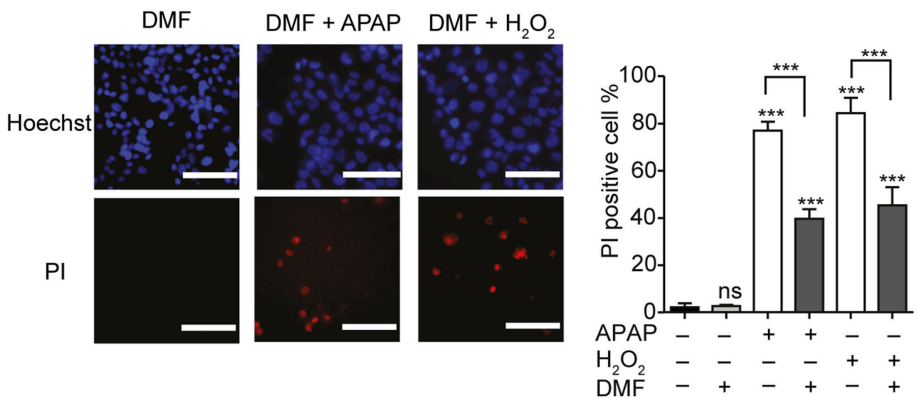

FIGURE 10 | GSH inducer DMF attenuate APAP- or $\mathrm{H}_{2} \mathrm{O}_{2}$-induced $\mathrm{Ca}^{2+}$ influx and ROS-mediated death in HepG2 cells. (A) The effects of 50, 100, and $200 \mu$ M DMF on GSH content in HepG2 cells. (B) The effects of 50, 100 and $200 \mu$ M DMF on cell viabilities in HepG2 cells. (C,D) DMF attenuated APAP- or $\mathrm{H}_{2} \mathrm{O}_{2}$-induced increases of ROS levels (C) and GSH depletion (D). (E) Averaged time courses and $\Delta\left[\mathrm{Ca}^{2+}\right]_{i}$ of APAP-(left) or $\mathrm{H}_{2} \mathrm{O}_{2}$-induced Ca ${ }^{2+}$ response (right) in the presence and absence of $100 \mu$ M DMF. (F-I) Effects of DMF on APAP- or $\mathrm{H}_{2} \mathrm{O}_{2}$-induced losses of cell viability (F) and increases of the activity of caspase $3 / 7$ (G), the level of intracellular cytochrome $\mathbf{c}(\mathbf{H})$, and the percentages of PI-positive cells (I) in HepG2 cells. $P \geq 0.05,{ }^{*} P<0.05,{ }^{* *} P<0.01$, and ${ }^{* \star *} P<0.001$ compared to DMSO or control. Differences not statistically significant are labeled as (ns). Data points are mean $\pm \mathrm{SEM}$. All data of $\left[\mathrm{Ca}^{2+}\right]_{\mathrm{i}}$ measurements were analyzed by Student's $t$-test, while other data were analyzed by ANOVA and Bonferroni post-hoc.

we cannot exclude the possibility that TRPV1 could operate as hetero-multimeric channel as well as homo-multimeric channel in response to APAP or $\mathrm{H}_{2} \mathrm{O}_{2}$.
ROS overproduction and the resulting cell damaging events are often accompanied by rises in $\left[\mathrm{Ca}^{2+}\right]_{i}$ (Yan et al., 2006). A previous report proposed that $\mathrm{H}_{2} \mathrm{O}_{2}$ alters cellular redox 


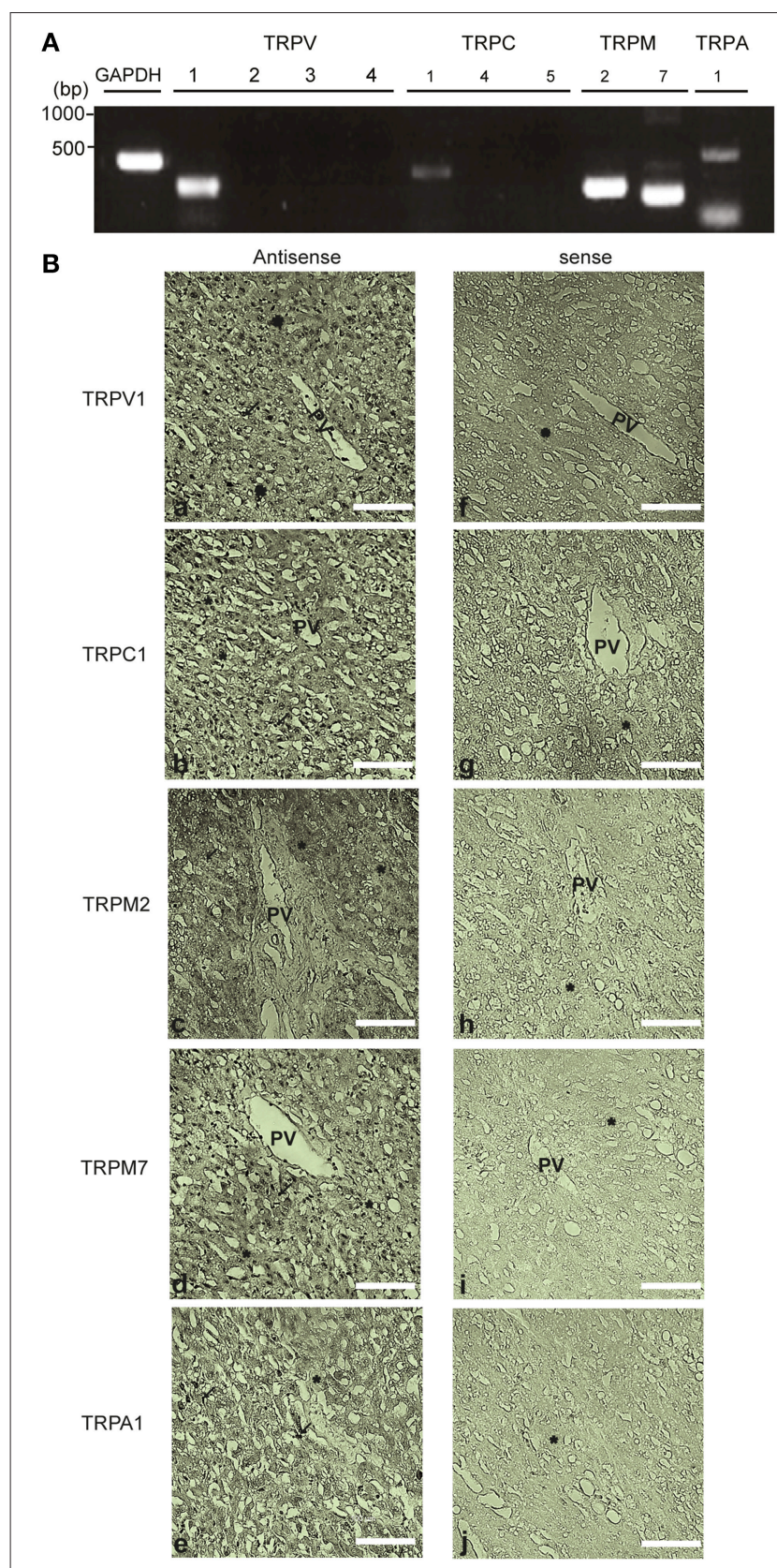

FIGURE 11 | Expression and localization of redox-sensitive TRP channel in the human liver tissue. (A) Expression of mRNAs for TRPV1-4, TRPC1, TRPC4, TRPC5, TRPM2, TRPM7, TRPA1, and GAPDH detected by PCR in the cDNA library from normal human liver. Specific PCR primers used are listed in the Table 1. (B) In situ hybridization analysis of TRPV1, TRPC1, TRPM2, TRPM7, and TRPA1 mRNAs in the paraffin section of the human liver. mRNAs of TRPV1 $(\mathbf{a}, \mathbf{f}), \operatorname{TRPC} 1 \mathbf{( b , g ) , ~ T R P M 2 ~}(\mathbf{c}, \mathbf{h}), \operatorname{TRPM} 7 \mathbf{( d , i )}$ were localized in hepatocytes $\left(^{*}\right)$ and Kupffer cells (arrow). TRPA1 $(\mathbf{e}, \mathbf{j})$ was localized in the lining of sinusoids and Kupffer cells of the human liver tissue. The images from the analysis of both the antisense (left) and sense probes (right) are shown. Scale bar, $100 \mu \mathrm{m}$.

status through increased $\left[\mathrm{Ca}^{2+}\right]_{\mathrm{i}}$, decreases GSH level and induces lipid peroxidation, eventually causing cell death in the human hepatoma cell line SMMC-7721 (Li et al., 2000).
Other reports suggested that APAP exposure leads to increased levels of superoxide anions, which upon dismutation generate $\mathrm{H}_{2} \mathrm{O}_{2}$ (Dai and Cederbaum, 1995). To clarify whether such mechanisms were involved in our experiments, we used NAC, a sulfhydryl drug, which contributes to repletion of GSH by diminishing ROS production via removal of superoxide radicals, $\mathrm{H}_{2} \mathrm{O}_{2}$, and hydroxyl radicals (Sen and Packer, 2000). NAC is the most widely used antidote for APAP-induced hepatotoxicity (Smilkstein et al., 1991). We also employed tiron, an intracellularly active scavenger of superoxide anions and hydroxyl radicals (Krishna et al., 1992; Taiwo, 2008). There had been no previous investigations addressing whether NAC or tiron actually suppress ROS and $\left[\mathrm{Ca}^{2+}\right]_{\mathrm{i}}$ in HepG2 cells. Importantly, we found that pretreatments with either NAC or tiron strongly attenuated APAP-induced elevations of ROS and $\left[\mathrm{Ca}^{2+}\right]_{\mathrm{i}}$ in HepG2 cells. This supports the hypothesized link between APAP overdose and ROS formation in HepG2 cells. Interestingly, it was reported that NAC reduced oxidative stress and suppressed TRPV1 channel-mediated $\mathrm{Ca}^{2+}$ entry in neutrophils from patients with polycystic ovary syndrome (Köse and Nazıroğlu, 2015). NAC may also play a protective role against $\mathrm{Ca}^{2+}$ influx through regulation of TRPM2 channels in neurons (Özgül and Nazıroğlu, 2012). It was further suggested that tiron reduced $\mathrm{Ca}^{2+}$ entry through TRPC1 channels in mouse muscle fibers (Gervásio et al., 2008). Taken together, NAC or tiron might work through suppression of APAP-elicited oxidative stress and ensuing activation of redox-sensitive TRP channels whose molecular expression was detected in HepG2 cells.

Consistent with our results, it was reported that TRPV1, TRPC1, TRPM2, and TRPM7 channels were modulated by ROS and induced deleterious responses such as cell death (Miller, 2006; Kozai et al., 2014b). For example, TRPV1 activation has previously been shown to increase $\left[\mathrm{Ca}^{2+}\right]_{i}$, oxidative stress and apoptotic cell death (Shin et al., 2003; Kim et al., 2006). TRPV1 and TRPC1 are activated by oxidative modification of free sulfhydryl groups of cysteine residues (Yoshida et al., 2006). We reported that TRPM2 induced cell death during conditions of oxidative stress (Hara et al., 2002). Suppression of TRPM7 expression by RNA interference blocked TRPM7 currents, anoxic $\mathrm{Ca}^{2+}$ influx, and ROS production, protecting cortical neurons from anoxia. This suggested a role for endogenous TRPM7 in anoxic neuronal death (Aarts et al., 2003). Thus, redox-sensitive TRP channels are widely involved in oxidative stress linked to cellular disorders.

$\mathrm{Ca}^{2+}$ dysregulation was reported to be involved in APAPinduced hepatocellular damage (Shen et al., 1991). It was suggested that $\left[\mathrm{Ca}^{2+}\right]_{i}$ increases are primarily caused by inhibition of $\mathrm{Ca}^{2+}-\mathrm{Mg}^{2+}$ ATPase and accompany, but do not cause, hepatocellular damage (Tsokos-Kuhn et al., 1988). In our study, pretreatment with antagonists of TRPV1, TRPC1, TRPM2, and TRPM7 channels (CPZ, 2-APB, CTZ, and AA861, respectively) protected the HepG2 cells from deleterious increases in $\mathrm{Ca}^{2+}$ entry and ROS production and the resulting cell death induced by APAP. Importantly, knockdown of these channels by a siRNA strategy resulted in significantly suppressed $\mathrm{Ca}^{2+}$ overload and ROS production 


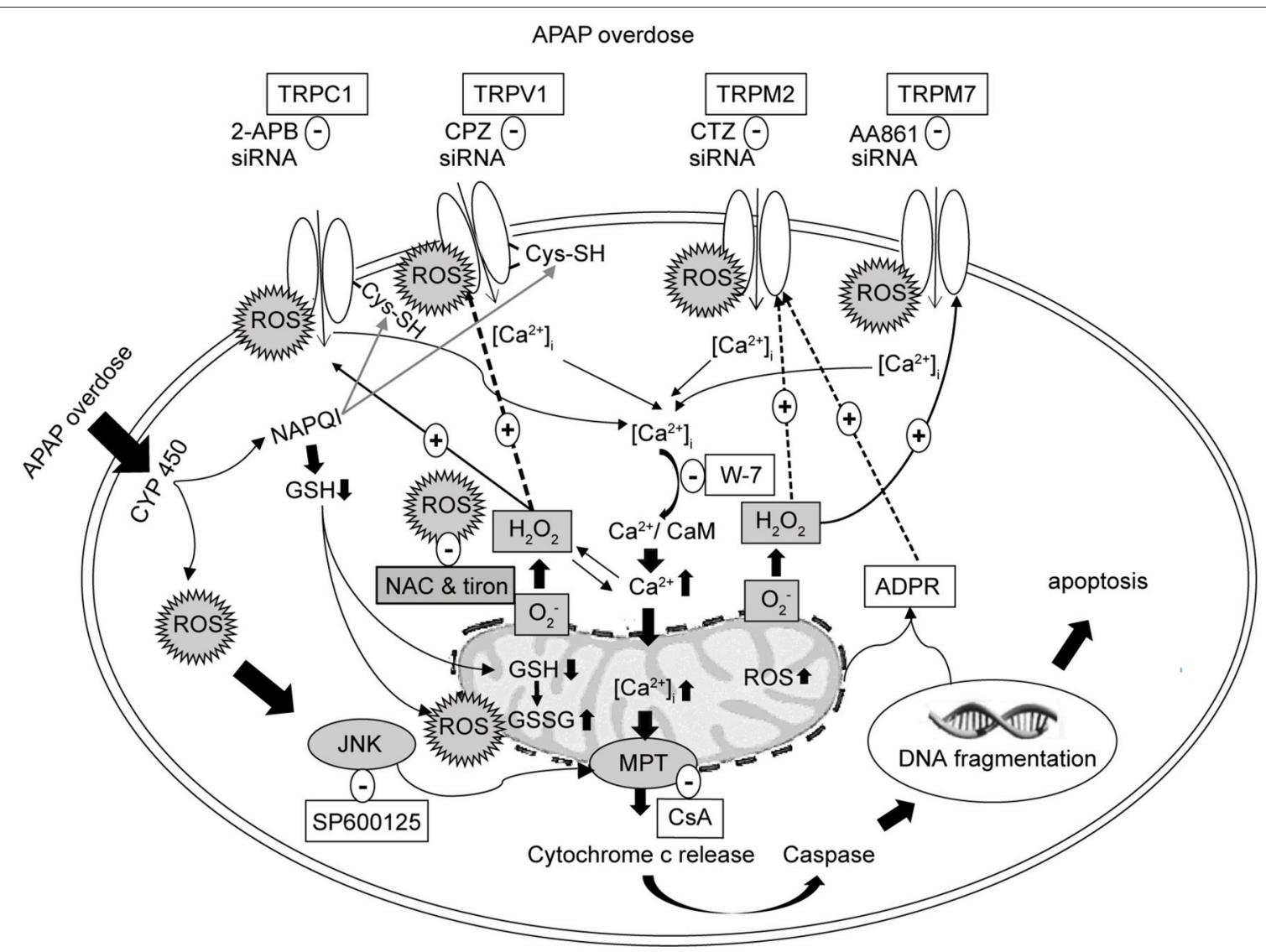

FIGURE 12 | Schematic representation of the proposed signaling mechanism underlying cell death regulated by $\mathrm{Ca}^{2+}$ entry via redox-sensitive TRPV1, TRPC1, TRPM2, and TRPM7 channels activated by APAP overdose in HepG2. TRPV1 and TRPC1 channels are activated by oxidative modification of free sulfhydryl groups of cysteine residues, which APAP is able to reach to enhance activation. Initial $\mathrm{Ca}^{2+}$ influx by APAP-induced ROS induces the mitochondrial and nuclear damages mediating the release of ADPR, which is released into the cytosol to activate TRPM2. ROS activates TRPM7. Suppression of TRPV1, TRPC1, TRPM2, and TRPM7 using blockers, siRNAs and ROS scavengers (NAC or tiron) alleviates APAP-induced $\mathrm{Ca}^{2+}$ entry and HepG2 death. APAP,

$\mathrm{N}$-acetyl-para-aminophenol; $\left[\mathrm{Ca}^{2+}\right]_{\mathrm{i}}$, calcium ions; HepG2, human hepatoma cell line; TRP, transient receptor potential channels; TRPV1, type 1 vanilloid receptor; TRPC1, type 1 canonical receptor; TRPM2, type 2 melastatin receptor; TRPM7, type 7 melastatin receptor; CaMs, calmodulins; CPZ, capsazepine (TRPV1 antagonist); 2-APB, 2-aminoethyl diphenylborinate (TRPC1 antagonist); CTZ, clotrimazole (TRPM2 antagonist); AA861,

2-(12-hydroxydodeca-5,10-diynyl)-3,5,6-trimethyl-p-benzoquinone (TRPM7 antagonist); CsA, cyclosporine A (inhibitor of mitochondrial permeability transition, MPT); $\mathrm{H}_{2} \mathrm{O}_{2}$, hydrogen peroxide; $\mathrm{O}_{2}^{-}$, superoxide anion; $\mathrm{ROS}$, reactive oxygen species; $\mathrm{GSH}$, glutathione; ADPR, adenosine diphosphate ribose; JNK, c-jun $\mathrm{NH} 2$-terminal kinase; NAC, $\mathrm{N}$-acetyl-L-cysteine.

in response to either APAP or $\mathrm{H}_{2} \mathrm{O}_{2}$. CTZ was previously reported to protect the liver against normothermic ischemiareperfusion injury in rats (Iannelli et al., 2009). Likewise, CPZ treatment conferred significant protection against liver dysfunction, as indicated by serum alanine transaminase (ALT) and aspartate transaminase (AST) activities, in sepsis (Ang et al., 2011). Moreover, 2-APB reduced APAP-induced liver injury in mouse primary hepatocytes in vivo (Du et al., 2013). In a recent study, AA861 pretreatment significantly attenuated acute liver failure in rats by inhibiting macrophage activation ( $\mathrm{Li}$ et al., 2014). Hence, abundant evidence indicates that activation of these TRP channels contributes to APAP-induced hepatotoxicity, raising a possibility that their blockers can ameliorate the APAP-induced damages of human hepatocytes.
Our data demonstrate that TRPC1 and TRPV1 play prominent roles in regulation of the APAP-induced responses among TRP channels expressed in HepG2 cells. Previously, we have reported that TRPV1 and TRPC1 are directly activated through oxidative modifications of cysteine residues by ROS, RNS, and electrophiles (Yoshida et al., 2006; Takahashi et al., 2011; Kozai et al., 2014b). In addition, previous reports have shown that endogenous expression of cytochrome P450 enzymes (CYPs), which convert APAP to its oxidized metabolite Nacetyl-p-benzoquinoneimine NAPQI, were detected in HepG2 cells (Sumida et al., 2000; Boess et al., 2003; Wilkening and Bader, 2003; Maruyama et al., 2007; El Gendy and El-Kadi, 2009; Hart et al., 2010; Wang et al., 2011). It is therefore possible that TRPV1 and TRPC1 are activated by NAPQI together with ROS/RNS generated upon APAP treatment to evoke pronounced 
downstream responses, compared with TRPM2 and TRPM7, which is most likely to be only activated by indirect action of ROS/RNS generated upon APAP treatment (Hara et al., 2002; Aarts et al., 2003). Interestingly, TRPA1, which is the most sensitive to oxidants and electrophiles among TRP channels (Takahashi et al., 2011), has been reported to respond to NAPQI to mediate spinal nociception induced by APAP in sensory neurons (Andersson et al., 2011). Alternatively, APAP itself may act directly but non-covalently to the DTNB-2Bio target cysteine residue(s), and activates TRPV1 and TRPC1. This possibility is likely when we consider our finding that APAP efficiently activates TRPV1 and TRPC1 expressed recombinant in HEK cells, in which expression of CYPs has not been clarified yet. At this point, we cannot conclude whether the action of APAP is through covalent binding of NAPQI or non-covalent binding of APAP itself, because both possibilities are consistent with our finding that treatment of permeabilized cells with APAP suppresses incorporation of DTNB-2Bio into TRPV1 and TRPC1 proteins (Figure 9). Thus, cysteine residues susceptible to oxidative modifications are critical for exacerbation of APAP-mediated hepatotoxicity in human, suggesting that TRP channels such as TRPC1 and TRPV1 susceptible to this type of modification are potential targets for the treatment of APAPinduced liver toxicity.

In our study, decrease in HepG2 cell viability as well as increases in DNA fragmentation, intracellular cytochrome c level, and caspase 3/7 activity were observed after either APAP overdose or $\mathrm{H}_{2} \mathrm{O}_{2}$ treatment. These responses were significantly reversed by ROS scavengers or TRP channel blockers. APAP overdose was previously reported to cause DNA fragmentation in primary cultured mouse hepatocytes (Shen et al., 1992) and mitochondrial cytochrome c release in isolated mouse liver cells (El-Hassan et al., 2003). Kim and colleagues suggested that oxidative stress and increased $\mathrm{Ca}^{2+}$ levels are both stimuli of mitochondrial dysfunction in rat hepatocytes (Kim et al., 2003). Downstream signaling of $\mathrm{Ca}^{2+}$ influx and $\mathrm{Ca}^{2+}$ overload in mitochondria can cause opening of the MPT pore (Zoratti and Szabò, 1995), and eventually promote apoptosis (Liu et al., 1996; Polster and Fiskum, 2004). The time required for this signaling cascade can possibly account for the time elapsed between $\mathrm{Ca}^{2+}$ concentration changes that took place within minutes and the observation of maximal HepG2 cell death at $24 \mathrm{~h}$ or more (Zhivotovsky and Orrenius, 2011). Collectively, these results suggest that mitochondrial $\mathrm{Ca}^{2+}$ overload might have contributed to APAP-induced HepG2 cell death in our study. Some reports claim that caspase activation and apoptosis were suggested to only occur in HepG2 but not in primary hepatocytes (Shen et al., 1992). However, activation of caspases in APAP-induced liver injury has been reported previously (Hu and Colletti, 2010; Sharma et al., 2011; Li et al., 2013), and such activation of caspases due to APAP treatment was significantly reduced in cells treated with anti-apoptotic caspases inhibitors (Ferret et al., 2001), which altogether would support an apoptotic pathway for APAP toxicity in hepatocytes.
We demonstrated that serum-deprived HepG2 cells are more susceptible than normally cultured cells to APAP- or $\mathrm{H}_{2} \mathrm{O}_{2}$ induced cell damage, depletion in GSH stores, increased $\mathrm{Ca}^{2+}$ influx, and loss of cell viability. Serum, a mixture of hundreds of proteins, contains various factors needed for proliferation of cells in culture (van der Valk et al., 2004). Serum deprivation may induce oxidative stress, caused by excess production of ROS or decreased GSH, and this can be inhibited by intracellular antioxidants (Pandey et al., 2003; Zhuge and Cederbaum, 2006).

Intracellular GSH is important for detoxification of a variety of chemicals, acting as a reductant in the metabolism of peroxides and free radicals (Circu and Aw, 2012). In addition, GSH is a crucial endogenous agent to restore the normal cellular redox state when it is compromised. Previous studies suggested that depletion of GSH by $\mathrm{H}_{2} \mathrm{O}_{2}$ is important for apoptosis and that $\mathrm{H}_{2} \mathrm{O}_{2}$-mediated lipid peroxidation might be a primary event leading to other biochemical changes (Li et al., 2000). It is possible that a decline in GSH content during APAP treatment similarly altered the cellular redox state in HepG2 cells. Our results showed that, in HepG2 cells, the GSH inducer DMF attenuated APAP- or $\mathrm{H}_{2} \mathrm{O}_{2}$-induced decrease in GSH content, increased ROS levels, $\mathrm{Ca}^{2+}$ overload, and cell death associated events such as intracellular cytochrome $c$ release and caspase 3/7 activation. DMF has been used successfully to treat multiple sclerosis (Fox et al., 2012), and psoriasis (Bovenschen et al., 2010), to attenuate renal fibrosis (Oh et al., 2012), and for cardioprotection (Ashrafian et al., 2012). It is believed to exert such benefits by restoring the balance between pro-oxidant and antioxidant systems during oxidative stress. DMF may therefore represent an alternative therapy to NAC, the current treatment for APAP hepatotoxicity.

In conclusion, this is the first study to systematically and comparatively analyze the contributions of redox-sensitive TRP channels such as TRPV1, TRPC1, TRPM2, and TRPM7 to human hepatoma cell death induced by APAP overdose. Our findings add considerably to current understanding of the mechanism of APAP-induced liver toxicity. Further comparative studies using various TRP knockout mice are important to establish individual roles in vivo of these TRP channels. Once our observation is confirmed in other models in vitro and in vivo, these TRP channels could represent potential drug targets for treating APAP overdose over a wide range of post-ingestion time.

\section{AUTHORS CONTRIBUTIONS}

$\mathrm{YM}, \mathrm{HB}$, and TN participated in research design; $\mathrm{HB}, \mathrm{DK}$, and TN conducted experiments and data collection; YM, HB, and TN performed data analysis and prepared figures; and YM, $\mathrm{HB}, \mathrm{TN}$, and RS wrote or contributed to the writing of the manuscript.

\section{FUNDING}

This work was supported by a Grant-in-Aid for Scientific Research on Innovative Areas "Oxygen biology: a new criterion 
for integrated understanding of life" (No. 26111004) of The Ministry of Education, Culture, Sports, Science and Technology, Japan.

\section{ACKNOWLEDGMENTS}

Human hepatoma cell line (HepG2; RCB1886) and human lung fibroblast cell line (WI-38; RCB0702) were provided by RIKEN Bio Resource Center with the support

\section{REFERENCES}

Aarts, M., Iihara, K., Wei, W. L., Xiong, Z. G., Arundine, M., Cerwinski, W., et al. (2003). A key role for TRPM7 channels in anoxic neuronal death. Cell 115, 863-877. doi: 10. 1016/S0092-8674(03)01017-1

Andersson, D. A., Gentry, C., Alenmyr, L., Killander, D., Lewis, S. E., Andersson, A., et al. (2011). TRPA1 mediates spinal antinociception induced by acetaminophen and the cannabinoid $\Delta(9)$-tetrahydrocannabiorcol. Nat. Commun. 2:551. doi: 10.1038/ncomms1559

Ang, S. F., Moochhala, S. M., MacAry, P. A., and Bhatia, M. (2011). Hydrogen sulfide and neurogenic inflammation in polymicrobial sepsis: involvement of substance $\mathrm{P}$ and ERK-NF- $\kappa \mathrm{B}$ signaling. PLoS ONE 6:e24535. doi: 10.1371/journal.pone.0024535

Ashrafian, H., Czibik, G., Bellahcene, M., Aksentijeviæ, D., Smith, A. C., Mitchell, S. J., et al. (2012). Fumarate is cardioprotective via activation of the Nrf2 antioxidant pathway. Cell Metab. 15, 361-371. doi: 10.1016/j.cmet.2012.01.017

Barritt, G. J., Chen, J., and Rychkov, G. (2008). Ca2+-permeable channels in the hepatocyte plasma membrane and their roles in hepatocyte physiology. Biochim. Biophys. Acta 1783, 651-672. doi: 10.1016/j.bbamcr.2008.01.016

Bessems, J. G., and Vermeulen, N. P. (2001). Paracetamol (acetaminophen)induced toxicity: molecular and biochemical mechanisms, analogues and protective approaches. Crit. Rev. Toxicol. 31, 55-138. doi: 10.1080/20014091111677

Boess, F., Kamber, M., Romer, S., Gasser, R., Muller, D., Albertini, S., et al. (2003). Gene expression in two hepatic cell lines, cultured primary hepatocytes, and liver slices compared to the in vivo liver gene expression in rats: possible implications for toxicogenomics use of in vitro systems. Toxicol. Sci. 73, 386-402. doi: 10.1093/toxsci/kfg064

Boulares, A. H., Zoltoski, A. J., Stoica, B. A., Cuvillier, O., and Smulson, M. E. (2002). Acetaminophen induces a caspase-dependent and $\mathrm{Bcl}-\mathrm{x}_{\mathrm{L}}$ sensitive apoptosis in human hepatoma cells and lymphocytes. Pharmacol. Toxicol. 90, 38-50. doi: 10.1034/j.1600-0773.2002.900108.x

Bovenschen, H. J., Langewouters, A. M., and van de Kerkhof, P. C. (2010). Dimethylfumarate for psoriasis: pronounced effects on lesional T-cell subsets, epidermal proliferation and differentiation, but not on natural killer $\mathrm{T}$ cells in immunohistochemical study. Am. J. Clin. Dermatol. 11, 343-350. doi: 10.2165/11533240-000000000-00000

Brereton, H. M., Chen, J., Rychkov, G., Harland, M. L., and Barritt, G. J. (2001). Maitotoxin activates an endogenous non-selective cation channel and is an effective initiator of the activation of the heterologously expressed hTRPC-1 (transient receptor potential) non-selective cation channel in H4-IIE liver cells. Biochim. Biophys. Acta 1540, 107-126. doi: 10.1016/S0167-4889(01)00124-0

Chen, H. C., Xie, J., Zhang, Z., Su, L. T., Yue, L., and Runnels, L. W. (2010). Blockade of TRPM7 channel activity and cell death by inhibitors of 5lipoxygenase. PLOS ONE 5:e11161. doi: 10.1371/journal.pone.0011161

Chen, J., and Barritt, G. J. (2003). Evidence that TRPC1 (transient receptor potential canonical 1) forms a $\mathrm{Ca}^{2+}$-permeable channel linked to the regulation of cell volume in liver cells obtained using small interfering RNA targeted against TRPC1. Biochem. J. 373, 327-336. doi: 10.1042/bj20021904

Chun, L. J., Tong, M. J., Busuttil, R.W., and Hiatt, J. R. (2009). Acetaminophen hepatotoxicity and acute liver failure. J. Clin. Gastroenterol. 43, 342-349. doi: 10.1097/MCG.0b013e31818a3854

Circu, M. L., and Aw, T. Y. (2012). Glutathione and modulation of cell apoptosis. Biochim. Biophys. Acta 1823, 1767-1777. doi: 10.1016/j.bbamcr.2012.06.019 of the National Bio Resource Project of the MEXT, Tsukuba, Japan. We thank Mr. Sawamura for experimental advice.

\section{SUPPLEMENTARY MATERIAL}

The Supplementary Material for this article can be found online at: http://journal.frontiersin.org/article/10.3389/fphar. 2016.00019

Clapham, D. E. (2003). TRP channels as cellular sensors. Nature 426, 517-524. doi: $10.1038 /$ nature02196

Dai, Y., and Cederbaum, A. I. (1995). Cytotoxicity of acetaminophen in human cytochrome P4502E1-transfected HepG2 cells. J. Pharmacol. Exp. Ther. 273, 1497-1505.

Denault, J. B., and Salvesen, G. S. (2002). Caspases: keys in the ignition of cell death Chem. Rev. 102, 4489-4500. doi: 10.1021/cr010183n

DeVries, J. (1981). Hepatotoxic metabolic activation of paracetamol and its derivatives phenacetin and benorilate: oxygenation or electron transfer. Biochem. Pharmacol. 30, 399-340.

Du, K., Williams, C. D., McGill, M. R., Xie, Y., Farhood, A., Vinken, M. et al. (2013). The gap junction inhibitor 2-aminoethoxy-diphenyl-borate protects against acetaminophen hepatotoxicity by inhibiting cytochrome $\mathrm{p} 450$ enzymes and c-jun N-terminal kinase activation. Toxicol. Appl. Pharmacol. 273, 484-491. doi: 10.1016/j.taap.2013.09.010

Duffy, S., So, A., and Murphy, T. H. (1998). Activation of endogenous antioxidant defenses in neuronal cells prevents free radical-mediated damage. J. Neurochem. 71, 69-77. doi: 10.1046/j.1471-4159.1998.71010069.x

El Boustany, C., Bidaux, G., Enfissi, A., Delcourt, P., Prevarskaya, N., and Capiod, T. (2008). Capacitative calcium entry and transient receptor potential canonical 6 expression control human hepatoma cell proliferation. Hepatology 47, 2068-2077. doi: 10.1002/hep.22263

El Gendy, M. A. M., and El-Kadi, A. O. S. (2009). Peganum harmala L. differentially modulates cytochrome P450 gene expression in human hepatoma HepG2 cells. Drug Metab. Lett. 3, 212-216. doi: 10.2174/187231209790218163

El-Hassan, H., Anwar, K., Macanas-Pirard, P., Crabtree, M., Chow, S. C., Johnson, V. L., et al. (2003). Involvement of mitochondria in acetaminopheninduced apoptosis and hepatic injury: roles of cytochrome c, Bax, Bid, and caspases. Toxicol. Appl. Pharmacol. 191, 118-129. doi: 10.1016/S0041-008X(03) 00240-0

Ferret, P.-J., Hammoud, R., Tulliez, M., Tran, A., Trébéden, H., Jaffray, P., et al. (2001). Detoxification of reactive oxygen species by a nonpeptidyl mimic of superoxide dismutase cures acetaminophen-induced acute liver failure. Hepatology 33, 1173-1180. doi: 10.1053/jhep.2001.24267

Fonfria, E., Murdock, P. R., Cusdin, F. S., Benham, C. D., Kelsell, R. E., and McNulty, S. (2006). Tissue distribution profiles of the human TRPM cation channel family. J. Recept. Signal Transduct. Res. 26, 159-178. doi: 10.1080/10799890600637506

Fox, R. J., Miller, D. H., Phillips, J. T., Hutchinson, M., Havrdova, E., Kita, M., et al. (2012). Placebo-controlled phase 3 study of oral BG-12 or Glatiramer in multiple sclerosis. N. Engl. J. Med. 367, 1087-1097. doi: 10.1056/NEJMoa1206328

Gervásio, O. L., Whitehead, N. P., Yeung, E. W., Phillips, W. D., and Allen, D. G. (2008). TRPC1 binds to caveolin-3 and is regulated by Src kinaserole in Duchenne muscular dystrophy. J. Cell Sci. 12, 2246-2255. doi: $10.1242 /$ jcs.032003

Hanano, T., Hara, Y., Shi, J., Morita, H., Umebayashi, C., Mori, E., et al. (2004). Involvement of TRPM7 in cell growth as a spontaneously activated $\mathrm{Ca}^{2+}$ entry pathway in human retinoblastoma cells. J. Pharmacol. Sci. 95, 403-419. doi: 10.1254/jphs.FP0040273

Hara, Y., Wakamori, M., Ishii, M., Maeno, E., Nishida, M., Yoshida, T., et al. (2002). LTRPC2 $\mathrm{Ca}^{2+}$-permeable channel activated by changes in redox status confers susceptibility to cell death. Mol. Cell. 9, 163-173. doi: 10.1016/S10972765(01)00438-5 
Hart, S. N., Li, Y., Nakamoto, K., Subileau, E. A., Steen, D., and Zhong, X. B. (2010). A comparison of whole genome gene expression profiles of HepaRG cells and HepG2 cells to primary human hepatocytes and human liver tissues. Drug Metab. Dispos. 38, 988-994. doi: 10.1124/dmd.109.031831

Hellwig, N., Albrecht, N., Harteneck, C., Schultz, G., and Schaefer, M. (2005). Homo- and heteromeric assembly of TRPV channel subunits. J. Cell Sci. 118, 917-928. doi: 10.1242/jcs.01675

Hinson, J. A., Roberts, D. W., and James, L. P. (2010). Mechanisms of acetaminophen-induced liver necrosis. Handb. Exp. Pharmacol. 196, 369-405. doi: 10.1007/978-3-642-00663-0 12

Hu, B., and Colletti, L. M. (2010). CXC receptor-2 knockout genotype increases $\mathrm{X}$-linked inhibitor of apoptosis protein and protects mice from acetaminophen hepatotoxicity. Hepatology 52, 691-702. doi: 10.1002/hep.23715

Hu, H., Tian, J., Zhu, Y., Wang, C., Xiao, R., Herz, J. M., et al. (2010). Activation of TRPA1 channels by fenamate nonsteroidal anti-inflammatory drugs. Pflugers Arch. 459, 579-592. doi: 10.1007/s00424-009-0749-9

Iannelli, A., de Sousa, G., Zucchini, N., Peyre, L., Gugenheim, J., and Rahmani, R. (2009). Clotrimazole protects the liver against normothermic ischemia-reperfusion injury in rats. Transplant. Proc. 41, 4099-4104. doi: 10.1016/j.transproceed.2009.08.074

Jaquemar, D., Schenker, T., and Trueb, B. (1999). An ankyrin-like protein with transmembrane domains is specifically lost after oncogenic transformation of human fibroblasts. J. Biol. Chem. 274, 7325-7333. doi: 10.1074/jbc.274. 11.7325

Jordt, S. E., Bautista, D. M., Chuang, H. H., McKemy, D. D., Zygmunt, P. M., Högestätt, E. D., et al. (2004). Mustard oils and cannabinoids excite sensory nerve fibers through the TRP channel ANKTM1. Nature 427, 260-265. doi: 10.1038 /nature 02282

Kheradpezhouh, E., Ma, L., Morphett, A., Barritt, G. J., and Rychkov, G. Y. (2014). TRPM2 channels mediate acetaminophen-induced liver damage. Proc. Natl. Acad. Sci. U.S.A. 111, 3176-3181. doi: 10.1073/pnas.1322657111

Kim, J. S., He, L., and Lemasters, J. J. (2003). Mitochondrial permeability transition: a common pathway to necrosis and apoptosis. Biochem. Biophys. Res. Commun. 304, 463-470. doi: 10.1016/S0006-291X(03)00618-1

Kim, S., Kang, C., Shin, C. Y., Hwang, S. W., Yang, Y. D., Shim, W. S., et al. (2006). TRPV1 recapitulates native capsaicin receptor in sensory neurons in association with Fas-associated factor 1. J. Neurosci. 26, 2403-2412. doi: 10.1523/JNEUROSCI.4691-05

Köse, S. A., and Nazıroğlu, M. (2015). N-acetyl cysteine reduces oxidative toxicity, apoptosis, and calcium entry through TRPV1 channels in the neutrophils of patients with polycystic ovary syndrome. Free Radic. Res. 49, 338-346. doi: 10.3109/10715762.2015.1006214

Kozai, D., Kabasawa, Y., Ebert, M., Kiyonaka, S., Firman, Otani, Y., et al. (2014a). Trans-nitrosylation directs TRPA1 selectivity in $\mathrm{N}$-nitrosamine activators. Mol. Pharmacol. 85, 175-185. doi: 10.1124/mol.113.088864

Kozai, D., Ogawa, N., and Mori, Y. (2014b). Redox regulation of transient receptor potential channels. Antioxid. Redox Signal. 21, 971-986. doi: 10.1089/ars.2013.5616

Krishna, C. M., Liebmann, J. E., Kaufman, D., DeGraff, W., Hahn, S. M., McMurry, T., et al. (1992). The catecholic metal sequestering agent 1,2-dihydroxybenzene3,5-disulfonate confers protection against oxidative cell damage. Arch. Biochem. Biophys. 294, 98-106. doi: 10.1016/0003-9861(92)90142-J

Lam, D. H., Grant, C. E., and Hill, C. E. (2012). Differential expression of TRPM7 in rat hepatoma and embryonic and adult hepatocytes. Can. J. Physiol. Pharmacol. 90, 435-444. doi: 10.1139/Y11-136

Lange, I., Yamamoto, S., Partida-Sanchez, S., Mori, Y., Fleig, A., and Penner, R. (2009). TRPM2 functions as a lysosomal $\mathrm{Ca}^{2+}$-release channel in beta cells. Sci Signal. 2:ra23. doi: 10.1126/scisignal.2000278

Larson, A. M., Polson, J., Fontana, R. J., Davern, T. J., Lalani, E., Hynan, L. S., et al. (2005). Acute Liver Failure Study Group. Acetaminophen-induced acute liver failure: results of a United States multicenter, prospective study. Hepatology 42, 1364-1372. doi: 10.1002/hep.20948

Li, G., Chen, J. B., Wang, C., Xu, Z., Nie, H., Qin, X. Y., et al. (2013). Curcumin protects against acetaminophen-induced apoptosis in hepatic injury. World J. Gastroenterol. 19, 7440-7446. doi: 10.3748/wjg.v19.i42.7440

Li, J., Huang, C. Y., Zheng, R. L., Cui, K. R., and Li, J. F. (2000). Hydrogen peroxide induces apoptosis in human hepatoma cells and alters cell redox status. Cell Biol. Int. 24, 9-23. doi: 10.1006/cbir.1999.0438
Li, L., Liu, Y. R., Gao, S., Li, J. F., Li, S. S., Zhang, D. D., et al. (2014). Inhibition of 5-Lipoxygenase pathway attenuates acute liver failure by inhibiting macrophage activation. J. Immunol. Res. 2014:697560. doi: 10.1155/2014/ 697560

Lievremont, J. P., Bird, G. S., and Putney, J. W. (2005). Mechanism of inhibition of TRPC cation channels by 2 -aminoethoxydiphenylborane. Mol. Pharmacol. 68, 758-762. doi: 10.1124/mol.105.012856

Liu, H., Li, J., Huang, Y., and Huang, C. (2012). Inhibition of transient receptor potential melastain 7 channel increases HSCs apoptosis induced by TRAIL. Life Sci. 90, 612-618. doi: 10.1016/j.lfs.2012.02.012

Liu, X., Kim, C. N., Yang, J., Jemmerson, R., and Wang, X. (1996). Induction of apoptotic program in cell-free extracts: requirement for dATP and cytochrome c. Cell 86, 147-157. doi: 10.1016/S0092-8674(00)80085-9

Maeno, E., Ishizaki, Y., Kanaseki, T., Hazama, A., and Okada, Y. (2000). Normotonic cell shrinkage because of disordered volume regulation is an early prerequisite to apoptosis. Proc. Natl. Acad. Sci. U.S.A. 97, 9487-9492. doi: $10.1073 /$ pnas.140216197

Maruyama, M., Matsunaga, T., Harada, E., and Ohmori, S. (2007). Comparison of basal gene expression and induction of CYP3As in HepG2 and human fetal liver cells. Biochem. Pharmacol. Bull. 30, 2091-2097. doi: 10.1248/bpb. 30.2091

McIntyre, P., McLatchie, L. M., Chambers, A., Phillips, E., Clarke, M., Savidge, J., et al. (2001). Pharmacological differences between the human and rat vanilloid receptor 1 (VR1). Br. J. Pharmacol. 132, 1084-1094. doi: 10.1038/sj.bjp.0703918

Miller, B. A. (2006). The role of TRP channels in oxidative stress-induced cell death. J. Membr. Biol. 209, 31-41. doi: 10.1007/s00232-005-0839-3

Mori, Y., Wakamori, M., Miyakawa, T., Hermosura, M., Hara, Y., Nishida, M., et al. (2002). Transient receptor potential 1 regulates capacitative $\mathrm{Ca}^{2+}$ entry and $\mathrm{Ca}^{2+}$ release from endoplasmic reticulum in B lymphocytes. J. Exp. Med. 195, 673-681. doi: 10.1084/jem.20011758

Muriel, P. (2009). Role of free radicals in liver diseases. Hepatol. Int. 3, 526-536. doi: 10.1007/s12072-009-9158-6

Myers, R. P., Li, B., Fong, A., Shaheen, A. A., and Quan, H. (2007). Hospitalizations for acetaminophen overdose: a Canadian population-based study from 1995 to 2004. BMC Public Health. 7:143. doi: 10.1186/1471-2458-7-143

Nazıroğlu, M., Özgül, C., Çiğ, B., Doğan, S., and Uğuz, A. C. (2011). Glutathione modulate $\mathrm{Ca}^{2+}$ influx and oxidative stress through TRPM2 channel in rat dorsal root ganglion neurons. J. Membr. Biol. 242, 109-118. doi: 10.1007/s00232-011-9382-6

Numata, T., Kiyonaka, S., Kato, K., Takahashi, N., and Mori, Y. (2011). “Activation of TRP channels in mammalian systems," in TRP Channels, ed M. X. Zhu (Boca Raton, FL: CRC Press), 43-90.

Oh, C. J., Kim, J. Y., Choi, Y. K., Kim, H. J., Jeong, J. Y., Bae, K. H., et al. (2012). Dimethylfumarate attenuates renal fibrosis via NF-E2-related factor 2 -mediated inhibition of transforming growth factor- $\beta /$ Smad signaling. PLoS ONE 7:e45870. doi: 10.1371/journal.pone.0045870

Özgül, C., and Nazıroğlu, M. (2012). TRPM2 channel protective properties of $\mathrm{N}$-acetylcysteine on cytosolic glutathione depletion dependent oxidative stress and $\mathrm{Ca}^{2+}$ influx in rat dorsal root ganglion. Physiol. Behav. 106, 122-128. doi: 10.1016/j.physbeh.2012.01.014

Pandey, S., Lopez, C., and Jammu, A. (2003). Oxidative stress and activation of proteasome protease during serum deprivation-induced apoptosis in rat hepatoma cells; inhibition of cell death by melatonin. Apoptosis 8, 497-508. doi: 10.1023/A:1025542424986

Polster, B. M., and Fiskum, G. (2004). Mitochondrial mechanisms of neural cell apoptosis. J. Neurochem. 90, 1281-1289. doi: 10.1111/j.1471-4159.2004.02572.x

Qian, T., Nieminen, A. L., Herman, B., and Lemasters, J. J. (1997). Mitochondrial permeability transition in $\mathrm{pH}$-dependent reperfusion injury to rat hepatocytes. Am. J. Physiol. 273, 1783-1792.

Rumack, B. H. (2004). Acetaminophen misconceptions. Hepatology 40, 10-15. doi: 10.1002/hep.20300

Rychkov, G. Y., and Barritt, G. J. (2011). Expression and function of TRP channels in liver cells. Adv. Exp. Med. Biol. 704, 667-686. doi: 10.1007/978-94-0070265-3_35

Salazar, H., Llorente, I., Jara-Oseguera, A., García-Villegas, R., Munari, M., Gordon, S. E., et al. (2008). A single N-terminal cysteine in TRPV1 determines activation by pungent compounds from onion and garlic. Nat. Neurosci. 11, 255-261. doi: 10.1038/nn2056 
Sen, C. K., and Packer, L. (2000). Thiol homeostasis and supplements in physical exercise. Am. J. Clin. Nutr. 72, 653-669.

Sharma, S., Singh, R. L., and Kakkar, P. (2011). Modulation of Bax/Bcl-2 and caspases by probiotics during acetaminophen induced apoptosis in primary hepatocytes. Food Chem. Toxicol. 49, 770-779. doi: 10.1016/j.fct.2010.11.041

Shen, W., Kamendulis, L. M., Ray, S. D., and Corcoran, G. B. (1991). Acetaminophen-induced cytotoxicity in cultured mouse hepatocytes: correlation of nuclear $\mathrm{Ca}^{2+}$, accumulation and early DNA fragmentation with cell death. Toxicol. Appl. Pharmacol. 111, 242-254.

Shen, W., Kamendulis, L. M., Ray, S. D., and Corcoran, G. B. (1992). Acetaminophen-induced cytotoxicity in cultured mouse hepatocytes: effects of $\mathrm{Ca}(2+)$-endonuclease, DNA repair, and glutathione depletion inhibitors on DNA fragmentation and cell death. Toxicol. Appl. Pharmacol. 112, 32-40.

Shin, C. Y., Shin, J., Kim, B. M., Wang, M. H., Jang, J. H., Surh, Y. J., et al. (2003). Essential role of mitochondrial permeability transition in vanilloid receptor 1dependent cell death of sensory neurons. Mol. Cell. Neurosci. 24, 57-68. doi: 10.1016/S1044-7431(03)00121-0

Smilkstein, M. J., Bronstein, A. C., Linden, C., Augenstein, W. L., Kulig, K. W., and Rumack, B. H. (1991). Acetaminophen overdose: a 48-hour intravenous $\mathrm{N}$-acetylcysteine treatment protocol. Ann. Emerg. Med. 20, 1058-1063. doi: 10.1016/S0196-0644(05)81352-6

Smith, G. D., Gunthorpe, M. J., Kelsell, R. E., Hayes, P. D., Reilly, P., Facer, P., et al. (2002). TRPV3 is a temperature-sensitive vanilloid receptor-like protein. Nature 418, 186-190. doi: 10.1038/nature00894

Sumida, A., Fukuen, S., Yamamoto, I., Matsuda, H., Naohara, M., and Azuma, J. (2000). Quantitative analysis of constitutive and inducible CYPs mRNA expression in the HepG2 cell line using reverse transcription-competitive PCR. Biochem. Biophys. Res. Commun. 267, 756-760. doi: 10.1006/bbrc.1999.2029

Taiwo, F. A. (2008). Mechanism of Tiron as scavenger of superoxide ions and free electrons. Spectroscopy 22, 491-498. doi: 10.3233/SPE-2008-0362

Takahashi, N., Kuwaki, K., Kiyonaka, S., Numata, T., Kozai, D., Mizuno, Y., et al. (2011). TRPA1 underlies a sensing mechanism for O2. Nat. Chem. Biol. 7, 701-711. doi: 10.1038/nchembio.640

Takahashi, N., Mizuno, Y., Kozai, D., Yamamoto, S., Kiyonaka, S., Shibata, T., et al. (2008). Molecular characterization of TRPAl channel activation by cysteine-reactive inflammatory mediators. Channels (Austin) 2, 287-298. doi: 10.4161/chan.2.4. 6745

Thomas, S. H. L. (1993). Paracetamol (acetaminophen) poisoning. Pharmacol. Ther. 60, 91-120. doi: 10.1016/0163-7258(93)90023-7

Tidyman, W. E., and Rauen, K. A. (2009). The RASopathies: developmental syndromes of Ras/MAPK pathway dysregulation. Curr. Opin. Genet. Dev. 19, 230-236. doi: 10.1016/j.gde.2009.04.001

Tsokos-Kuhn, J. O., Hughes, H., Smith, C. V., and Mitchell, J. R. (1988). Alkylation of the liver plasma membrane and inhibition of the $\mathrm{Ca}^{2+}$ ATPase by acetaminophen. Biochem. Pharmacol. 37, 2125-2131. van der Valk, J., Mellor, D., Brands, R., Fischer, R., Gruber, F., Gstraunthaler, G., et al. (2004). The humane collection of fetal bovine serum and possibilities for serum-free cell and tissue culture. Toxicol. In Vitro. 18, 1-12. doi: 10.1016/j.tiv.2003.08.009

Voets, T., and Nilius, B. (2003). TRPs make sense. J Membr. Biol. 192, 1-8. doi: 10.1007/s00232-002-1059-8

Vriens, J., Janssens, A., Prenen, J., Nilius, B., and Wondergem, R. (2004). TRPV channels and modulation by hepatocyte growth factor/scatter factor in human hepatoblastoma (HepG2) cells. Cell Calcium 36, 19-29. doi: 10.1016/j.ceca.2003.11.006

Wang, Q. L., Wu, Q., Tao, Y. Y., Liu, C. H., and El-Nezami, H. (2011). Salvianolic acid B modulates the expression of drug-metabolizing enzymes in HepG2 cells. Hepatobiliary Pancreat. Dis. Int. 10, 502-508. doi: 10.1016/S14993872(11)60085-4

Wilkening, S., and Bader, A. (2003). Influence of culture time on the expression of drug-metabolizing enzymes in primary human hepatocytes and hepatoma cell line HepG2. J. Biochem. Mol. Toxicol. 17, 207-213. doi: 10.1002/jbt. 10085

Yan, Y., Wei, C. L., Zhang, W. R., Cheng, H. P., and Liu, J. (2006). Cross-talk between calcium and reactive oxygen species signaling. Acta Pharmacol. Sin. 27, 821-826. doi: 10.1111/j.1745-7254.2006. 00390.x

Yoshida, T., Inoue, R., Morii, T., Takahashi, N., Yamamoto, S., Hara, Y., et al. (2006). Nitric oxide activates TRP channels by cysteine S-nitrosylation. Nat. Chem. Biol. 2, 596-607. doi: 10.1038/nchembio821

Zhivotovsky, B., and Orrenius, S. (2011). Calcium and cell death mechanisms: a perspective from the cell death community. Cell Calcium 50, 211-221. doi: 10.1016/j.ceca.2011.03.003

Zhuge, J., and Cederbaum, A. I. (2006). Serum deprivation-induced HepG2 cell death is potentiated by CYP2E1. Free Radic. Biol. Med. 40, 63-74. doi: 10.1016/j.freeradbiomed.2005.08.012

Zoratti, M., and Szabò, I. (1995). The mitochondrial permeability transition. Biochim. Biophys. Acta 1241, 139-176. doi: 10.1016/0304-4157(95) 00003-A

Conflict of Interest Statement: The authors declare that the research was conducted in the absence of any commercial or financial relationships that could be construed as a potential conflict of interest.

Copyright () 2016 Badr, Kozai, Sakaguchi, Numata and Mori. This is an open-access article distributed under the terms of the Creative Commons Attribution License (CC $B Y)$. The use, distribution or reproduction in other forums is permitted, provided the original author(s) or licensor are credited and that the original publication in this journal is cited, in accordance with accepted academic practice. No use, distribution or reproduction is permitted which does not comply with these terms. 